\title{
Evaluation of the sectional aerosol microphysics module SALSA implementation in ECHAM5-HAM aerosol-climate model
}

\author{
T. Bergman ${ }^{1,2}$, V.-M. Kerminen ${ }^{2,3}$, H. Korhonen ${ }^{1}$, K. J. Lehtinen ${ }^{1,4}$, R. Makkonen ${ }^{2}$, A. Arola ${ }^{1}$, T. Mielonen ${ }^{1}$, \\ S. Romakkaniemi ${ }^{4}$, M. Kulmala ${ }^{2}$, and H. Kokkola ${ }^{1}$ \\ ${ }^{1}$ Finnish Meteorological Institute, Kuopio Unit, Kuopio, Finland \\ ${ }^{2}$ University of Helsinki, Department of Physics, Helsinki, Finland \\ ${ }^{3}$ Finnish Meteorological Institute, Climate Change, Helsinki, Finland \\ ${ }^{4}$ University of Eastern Finland, Department of Applied Physics, Kuopio, Finland
}

Correspondence to: T. Bergman (tommi.bergman@iki.fi)

Received: 18 November 2011 - Published in Geosci. Model Dev. Discuss.: 14 December 2011

Revised: 10 May 2012 - Accepted: 12 May 2012 - Published: 18 June 2012

\begin{abstract}
We present the implementation and evaluation of a sectional aerosol microphysics module SALSA within the aerosol-climate model ECHAM5-HAM. This aerosol microphysics module has been designed to be flexible and computationally efficient so that it can be implemented in regional or global scale models. The computational efficiency has been achieved by minimising the number of variables needed to describe the size and composition distribution. The aerosol size distribution is described using 10 size classes with parallel sections which can have different chemical compositions. Thus in total, the module tracks 20 size sections which cover diameters ranging from $3 \mathrm{~nm}$ to $10 \mu \mathrm{m}$ and are divided into three subranges, each with an optimised selection of processes and compounds.

The implementation of SALSA into ECHAM5-HAM includes the main aerosol processes in the atmosphere: emissions, removal, radiative effects, liquid and gas phase sulphate chemistry, and the aerosol microphysics. The aerosol compounds treated in the module are sulphate, organic carbon, sea salt, black carbon, and mineral dust. In its default configuration, ECHAM5-HAM treats aerosol size distribution using the modal method. In this implementation, the aerosol processes were converted to be used in a sectional model framework.

The ability of the module to describe the global aerosol properties was evaluated by comparing against (1) measured continental and marine size distributions, (2) observed variability of continental number concentrations, (3) measured sulphate, organic carbon, black carbon and sea-salt mass concentrations, (4) observations of aerosol optical depth
\end{abstract}

(AOD) and other aerosol optical properties from satellites and AERONET network, (5) global aerosol budgets and concentrations from previous model studies, and (6) model results using M7, which is the default aerosol microphysics module in ECHAM5-HAM.

The evaluation shows that the global aerosol properties can be reproduced reasonably well using a coarse resolution of 10 sections in size space. The simulated global aerosol budgets are within the range of previous studies. Surface concentrations of sulphate and carbonaceous species have an annual mean within a factor of two of the observations. The simulated sea-salt concentrations reproduce the observations within a factor of two, apart from the Southern Ocean over which the concentrations are within a factor of five. Regionally, AOD is in a relatively good agreement with the observations (within a factor of two). At mid-latitudes the observed AOD is captured well, while at high-latitudes as well as in some polluted and dust regions the modelled AOD is significantly lower than observed.

Regarding most of the investigated aerosol properties, the SALSA and the modal aerosol module M7 perform comparably well against observations. However, SALSA reproduces the observed number concentrations and the size distribution of CCN sized particles much more accurately than M7, and is therefore a good choice for aerosol-cloud interaction studies in global models. Our study also shows that when activation type nucleation in the boundary layer is included, the observed concentration of particles under $50 \mathrm{~nm}$ in diameter are reproduced much better compared to when only binary nucleation in the free troposphere is assumed. 


\section{Introduction}

Aerosols and their interactions with clouds constitute the largest uncertainty in the estimation of present-day radiative forcing of the Earth's atmosphere (Forster et al., 2007; Myhre, 2009; Quaas et al., 2009), hindering seriously our ability to predict the future climate change (Schwartz et al., 2010). Reducing this uncertainty requires detailed information on the spatial and temporal variability of the concentration, number size distribution and chemical composition of aerosol particles throughout the atmosphere. Necessary tools for getting such detailed information are large-scale modelling frameworks together with various measurements platforms (Ghan and Schwartz, 2007).

The size-resolved chemical composition of atmospheric aerosols can be simulated in several ways. The most accurate and flexible in terms of the shape of the size distribution is the sectional method (e.g. Jacobson, 2001; Adams and Seinfeld, 2002; Spracklen et al., 2005); however, it is also computationally the most demanding. In this approach the aerosol population is typically divided into a relatively large number of fixed size bins, and the particle number concentration and mass concentrations of different chemical constituents are being tracked separately for each size bin. The second commonly-used method is the modal method that describes the aerosol population with a few log-normal modes (e.g. Binkowski and Roselle, 2003; Vignati et al., 2004; Stier et al., 2005; Sartelet et al., 2006; Pringle et al., 2010; Mann et al., 2010; Zhang et al., 2010). The modal approach is typically much faster than the sectional method, but it has some challenges in accurately describing many climatically important processes, including cloud droplet activation and atmospheric new-particle formation and growth (Zhang et al., 1999; Sartelet et al., 2006). A more rarely-used approach is the moment method, in which all aerosol processes are tied into different moments of the particle number size distribution (e.g. Bauer et al., 2008). In this method, aerosol properties require an off-line calculation, so this approach can be considered rather inconvenient when interpreting model simulations and comparing the simulations with atmospheric measurements.

Due to computational limitations, most existing largescale modelling frameworks employ either a modal approach or, alternatively, some combination of modal and sectional or even bulk (only aerosol mass) approaches (e.g. Liu et al., 2005a; Reddy et al., 2005; Liao et al., 2009). The sectional module SALSA (Kokkola et al., 2008) was designed to reduce the computational burden of traditional sectional models via optimisation of model performance without losing aerosol information relevant to climate simulations. To obtain this, the aerosol size distribution is divided into 3 subranges, each with different bin widths and degree of aerosol external mixing. The number of chemical compounds and active processes modelled vary also from one subrange to another. With these simplifications, the number of size bins, and thus the computational burden, can be reduced significantly without neglecting any of the most significant processes or chemical compounds. Comparison to a detailed sectional aerosol model demonstrated that SALSA is capable of accurately simulating the basic aerosol microphysical processes in a zero dimensional framework (Kokkola et al., 2008). The main advantage of SALSA compared to modal models is that the sectional method is more flexible in presenting the particle size distribution, which can significantly affect, e.g. cloud activation predictions.

In this work, we present an evaluation of the SALSA module in the global general circulation modelling framework ECHAM5. We compare the aerosol representation of SALSA to that of the M7 modal model, which is also implemented in ECHAM5 (Stier et al., 2005) and which has been applied in several studies (e.g. Lohmann et al., 2007; Hoose et al., 2008; Sesartic et al., 2011; O'Donnell et al., 2011; Partanen et al., 2012). Our comparison focuses on global aerosol budgets, aerosol optical properties and particle number size distributions. To assess the qualitative correctness of the representation, comparisons to in situ measurements and satellite observations are performed as well.

\section{Model description}

\subsection{Aerosol-climate model ECHAM5-HAM}

The atmospheric general circulation model ECHAM5, developed at Max Planck Institute for Meteorology, is a fifthgeneration global climate model (Roeckner et al., 2003, 2004). The prognostic equations are solved as spherical harmonics with triangular truncation. In ECHAM5, the horizontal grid is discretised using the spectral transform method. Grid-point calculations are done in a Gaussian grid. For vertical discretisation, ECHAM5 uses the hybrid $\sigma$-pressure coordinates with a pressure range from $1013 \mathrm{hPa}$ to $10 \mathrm{hPa}$. In this study, we have used a spectral truncation of 63 (corresponding to approximately $1.9^{\circ} \times 1.9^{\circ}$ on the Gaussian grid) and 31 levels in the vertical. The time step for this resolution is $12 \mathrm{~min}$. Large scale transport uses the Flux Form SemiLangrangian (FFSL) method by Lin and Rood (1996).

The Hamburg Aerosol Model (HAM) (Stier et al., 2005) handles the emissions, removal and microphysics of aerosol particles within ECHAM5. Emissions and removal processes are partly calculated on-line and partly prescribed. In the earlier studies using ECHAM5-HAM, the aerosol microphysics has been calculated using the M7 modal aerosol model by Vignati et al. (2004). In our study we have replaced the M7 model with the SALSA module and compared the differences.

\subsection{Nudging}

In this study, the simulations are run using the nudging method described by Jeuken et al. (1996). This method 


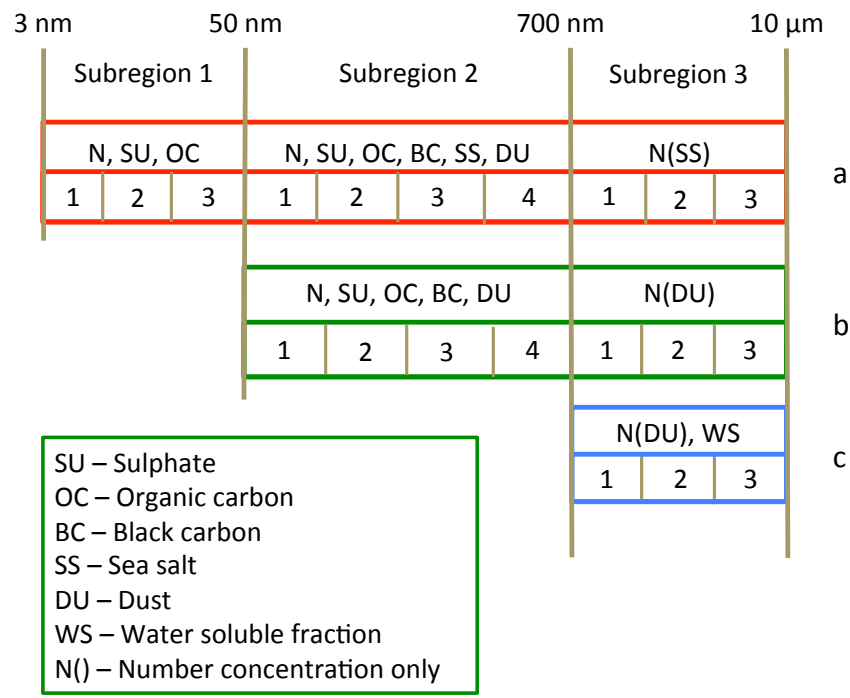

Fig. 1. Schematic of the SALSA sectional structure. There are three parallel sections $\mathrm{a}, \mathrm{b}$ and $\mathrm{c}$ in three subranges, each consisting of three or four sections. Parallel size sections in subclass a are soluble, in subclass $b$ insoluble and in subclass $c$ insoluble, with possibility for soluble coating enabling cloud activation.

relaxes the synoptic scale meteorology towards observed atmospheric conditions by using atmospheric re-analysis data, in our case the ECMWF (The European Centre for MediumRange Weather Forecasts) operational re-analysis data (Uppala et al., 2005). While the modelled meteorological fields with nudging are to some extent affected by the model configuration (and thus can differ slightly between two model runs due to, e.g. different aerosol forcings), nudging is the best way to quantify the differences in aerosol population that are induced by differences in the aerosol models within the ECHAM5-HAM aerosol-climate model. The simulations with both models are performed for the period from July 2007 to December 2008. Spin-up spans the first six months and analysis is done for year 2008 .

\subsection{SALSA module}

The SALSA module describes the aerosol population with a moving center sectional approach (Jacobson, 1997b). SALSA is constructed to allow for flexible modification of the number of sections as well as the locations of the boundaries between subranges. In the setup used in this study, the size distribution of SALSA consists of 10 size classes with parallel chemical compositions (i.e. some degree of external mixing) and thus simulates 20 sections in total (see Fig. 1). These sections cover diameters ranging from $3 \mathrm{~nm}$ to $10 \mu \mathrm{m}$ and the diameter range is divided into three subranges, each with three or four size sections. The size section boundaries within subranges are spaced logarithmically and shown in Table 1.
Table 1. Particle diameter limits within all sections in SALSA Please note that the limits in parallel size bins are the same.

\begin{tabular}{llrrr}
\hline Bin & Solubility & $\begin{array}{r}\text { Minimum } \\
\text { diameter }\end{array}$ & $\begin{array}{r}\text { Maximum } \\
\text { diameter }\end{array}$ & $\begin{array}{r}\text { Volume mean } \\
\text { diameter }\end{array}$ \\
\hline 1a1 & soluble & $3.00 \mathrm{~nm}$ & $7.7 \mathrm{~nm}$ & $6.2 \mathrm{~nm}$ \\
1a2 & soluble & $7.7 \mathrm{~nm}$ & $19.6 \mathrm{~nm}$ & $15.8 \mathrm{~nm}$ \\
1a3 & soluble & $19.6 \mathrm{~nm}$ & $50.0 \mathrm{~nm}$ & $40.5 \mathrm{~nm}$ \\
2a1 & soluble & $50.0 \mathrm{~nm}$ & $96.7 \mathrm{~nm}$ & $80.1 \mathrm{~nm}$ \\
2a2 & soluble & $96.7 \mathrm{~nm}$ & $187.0 \mathrm{~nm}$ & $155.0 \mathrm{~nm}$ \\
2a3 & soluble & $187 \mathrm{~nm}$ & $362.0 \mathrm{~nm}$ & $300.0 \mathrm{~nm}$ \\
2a4 & soluble & $362 \mathrm{~nm}$ & $700.0 \mathrm{~nm}$ & $580.1 \mathrm{~nm}$ \\
2b1 & insoluble & $50.0 \mathrm{~nm}$ & $96.7 \mathrm{~nm}$ & $80.1 \mathrm{~nm}$ \\
2b2 & insoluble & $96.7 \mathrm{~nm}$ & $187.0 \mathrm{~nm}$ & $155.0 \mathrm{~nm}$ \\
2b3 & insoluble & $187.0 \mathrm{~nm}$ & $362.0 \mathrm{~nm}$ & $300.0 \mathrm{~nm}$ \\
2b4 & insoluble & $362.0 \mathrm{~nm}$ & $700.0 \mathrm{~nm}$ & $580.1 \mathrm{~nm}$ \\
3a1 & soluble & $0.70 \mu \mathrm{m}$ & $1.70 \mu \mathrm{m}$ & $1.38 \mu \mathrm{m}$ \\
3a2 & soluble & $1.70 \mu \mathrm{m}$ & $4.12 \mu \mathrm{m}$ & $3.35 \mu \mathrm{m}$ \\
3a3 & soluble & $4.12 \mu \mathrm{m}$ & $10.0 \mu \mathrm{m}$ & $8.12 \mu \mathrm{m}$ \\
3b1 & insoluble & $0.70 \mu \mathrm{m}$ & $1.70 \mu \mathrm{m}$ & $1.38 \mu \mathrm{m}$ \\
3b2 & insoluble & $1.70 \mu \mathrm{m}$ & $4.12 \mu \mathrm{m}$ & $3.35 \mu \mathrm{m}$ \\
3b3 & insoluble & $4.12 \mu \mathrm{m}$ & $10.0 \mu \mathrm{m}$ & $8.12 \mu \mathrm{m}$ \\
3c1 & insoluble & $0.70 \mu \mathrm{m}$ & $1.70 \mu \mathrm{m}$ & $1.38 \mu \mathrm{m}$ \\
3c2 & insoluble & $1.70 \mu \mathrm{m}$ & $4.12 \mu \mathrm{m}$ & $3.35 \mu \mathrm{m}$ \\
3c3 & insoluble & $4.12 \mu \mathrm{m}$ & $10.0 \mu \mathrm{m}$ & $8.12 \mu \mathrm{m}$ \\
\hline
\end{tabular}

To reduce the computational burden of the module, only the most relevant chemical compounds and microphysical processes are included for each size range. The simulated processes are listed in Table 2 and the compounds in Table 3. Note that in subrange $3 \mathrm{c}$ the chemical compounds are not simulated explicitly but lumped into insoluble (i.e. dust) and soluble components. The soluble component includes water soluble compounds (sulphate and organic carbon) transferred from subrange $2 \mathrm{~b}$ after growth over $700 \mathrm{~nm}$.

The prognostic variables for each section in subranges 1 and 2 are the particle number concentration and the mass concentrations of different chemical components. In the third subrange, the mean diameter is fixed and the only prognostic variable in ranges $3 \mathrm{a}$ and $3 \mathrm{~b}$ is number concentration. In subrange $3 \mathrm{c}$, the mass concentration of water soluble (WS) coating on the particles is a prognostic variable.

Subrange 1 consists of three sections and there are no parallel size sections (i.e. no external mixing). This subrange consists mainly of freshly nucleated particles with a particle diameter between $3 \mathrm{~nm}$ and $50 \mathrm{~nm}$. The particle compounds include only sulphate and organic carbon.

Particle diameters between $50 \mathrm{~nm}$ and $700 \mathrm{~nm}$ reside in subrange 2. This subrange has two externally mixed sections for each of the four size classes. The externally mixed sections are separated by their solubility, which represents their ability to act as cloud condensation nuclei. This subrange contains all compounds: organic and black carbon, sulphate, sea salt and mineral dust. The soluble sections include 
Table 2. The processes have been limited to certain size ranges. Coagulation of large particles is not considered due to low importance. Dry deposition and sedimentation have very limited effect on the population in the smaller soluble size ranges. Nucleation creates new particles only in the smallest size section.

\begin{tabular}{lcccccc}
\hline Process & $1 \mathrm{a}$ & $2 \mathrm{a}$ & $2 \mathrm{~b}$ & $3 \mathrm{a}$ & $3 \mathrm{~b}$ & $3 \mathrm{c}$ \\
\hline Nucleation & $\circ$ & & & & & \\
Condensation & $\circ$ & $\circ$ & $\circ$ & $\circ$ & $\circ$ & $\circ$ \\
Coagulation & $\circ$ & $\circ$ & $\circ$ & & & \\
Wet deposition & $\circ$ & $\circ$ & $\circ$ & $\circ$ & $\circ$ & $\circ$ \\
Dry deposition & $\circ$ & $\circ$ & $\circ$ & $\circ$ & $\circ$ & $\circ$ \\
Sedimentation & & $\circ$ & $\circ$ & $\circ$ & $\circ$ & $\circ$ \\
\hline
\end{tabular}

all compounds excluding dust, while the insoluble particle sections include all compounds excluding sea salt.

The three size sections in subrange 3 cover the particle size from $700 \mathrm{~nm}$ to $10 \mu \mathrm{m}$ and have three parallel chemical compositions. Most of the particles originate from natural sources. The three externally mixed parallel compositions sea salt, aged particles from subrange 2 and insoluble dust with water soluble coating. The water soluble compounds sulphate and organic carbon grown from subrange $2 b$ are treated as one compound (water soluble - WS) within the insoluble dust group.

\subsection{Microphysical processes}

One of the computationally most expensive processes in modelling the aerosol population is coagulation. Therefore, coagulation is calculated for each bin so that particles can only collide with larger particles. However, there is an exception for subrange $2 \mathrm{~b}$ where particles can also collide with the same-sized particles in subrange 2a. Neglecting self-coagulation may cause some error in the smallest size bins; however, generally coagulation with larger particles is much more likely than with equal sized particles. Coagulation is neglected when both colliding particles have diameters exceeding $700 \mathrm{~nm}$ due to small coagulation coefficients (Seinfeld and Pandis, 2006).

The mass transfer of gaseous $\mathrm{H}_{2} \mathrm{SO}_{4}$ onto particle surfaces is calculated using Analytical Predictor of Condensation (APC) scheme (Jacobson, 1997a) with the saturation vapor pressure set to zero. APC scheme solves the mass transfer without iteration while conserving mass exactly, and is unconditionally stable. For the coagulation collision rate, we use the expression by Lehtinen et al. (2004). The coagulation collision scheme is an accurate, discrete method for calculating coagulation of nucleation mode particles. For simultaneous calculation of nucleation and condensation, we use the operator splitting technique developed by Jacobson (2002). Operator splitting technique allows for realistic competition among size sections for sulphuric acid available for nucleation and condensation.
Table 3. Compound distribution in the three subranges. Characters a-c after subrange indicator refer to parallel subranges for different chemical compositions. In subrange 3 the number concentration is assumed to consist in solely seasalt or dust (marked with [o]).

\begin{tabular}{llcccccc}
\hline & Abbrev. & $1 \mathrm{a}$ & $2 \mathrm{a}$ & $2 \mathrm{~b}$ & $3 \mathrm{a}$ & $3 \mathrm{~b}$ & $3 \mathrm{c}$ \\
\hline Sulphate & SU & $\circ$ & $\circ$ & $\circ$ & & & \\
Organic carbon & OC & $\circ$ & $\circ$ & $\circ$ & & & \\
Black carbon & BC & & $\circ$ & $\circ$ & & & \\
Sea salt & SS & & $\circ$ & & {$[\circ]$} & & \\
Dust & DU & & $\circ$ & $\circ$ & & {$[\circ]$} & {$[\circ]$} \\
Water soluble & WS & & & & & & $\circ$ \\
\hline
\end{tabular}

The equilibrium wet diameter of particles in different size sections are calculated using the Zdanovskii-StokesRobinson (ZSR) method (Stokes and Robinson, 1966). To reduce the computational burden, hydration is calculated only for soluble size bins. In the calculation of hydration, we use binary molalities for inorganic salts according to parameterisations given by Jacobson (2005).

\subsubsection{New particle formation}

Particle number in the atmosphere can increase in two different ways: particles can emerge (1) as primary particles from emissions or (2) as secondary particles by going through the gas-particle transformation-nucleation. For the calculation of nucleation, the current setup uses the parameterised sulphuric acid-water binary homogeneous nucleation parameterisation (Vehkamäki et al., 2002) in the free troposphere, and three optional mechanisms in the boundary layer: binary homogeneous nucleation, and two empirical parameterisations for kinetic (Sihto et al., 2006; Riipinen et al., 2007) and activation nucleation (Kulmala et al., 2006; Riipinen et al., 2007).

Both activation-type and kinetic-type nucleation parameterisations calculate the $1 \mathrm{~nm}$ particle formation rate as a function of sulphuric acid concentration

$J_{1}=K\left[\mathrm{H}_{2} \mathrm{SO}_{4}\right]^{l}$,

where $K$ is the empirically defined activation (or kinetic) coefficient and $l$ is the nucleation exponent, which is 1 for the activation and 2 for kinetic nucleation schemes. In this study, we have used $K=1 \times 10^{-7} \mathrm{~s}^{-1}$ for activation nucleation ( $\mathrm{Si}$ hto et al., 2006; Riipinen et al., 2007). The binary homogeneous nucleation is parameterised as a function of temperature, relative humidity and sulphuric acid, as described by Vehkamäki et al. (2002).

Nucleation from all three simulated mechanisms produces particles that have a diameter of approximately $1 \mathrm{~nm}$. As the smallest section in SALSA has a lower limit of $3 \mathrm{~nm}$, the growth of these freshly nucleated particles from $1 \mathrm{~nm}$ to $3 \mathrm{~nm}$ 
by molecular collisions and condensation must be calculated before the particles can be inserted into section 1a1.

In this study the growth from $1 \mathrm{~nm}$ to $3 \mathrm{~nm}$ is calculated using the Kerminen and Kulmala (2002) parameterisation. This parameterisation has the form

$J_{3}=J_{1} \exp \left(\gamma \frac{\mathrm{CS}}{\mathrm{GR}}\right)$,

where $J_{1}$ and $J_{3}$ are the formation rates of $1 \mathrm{~nm}$ and $3 \mathrm{~nm}$ particles. $\gamma$ is a parameter calculated on-line and depends on the particle population and temperature. CS is the condensation sink representing surface of pre-existing aerosol particles consuming condensing vapors, and GR is the nuclei growth rate calculated from the concentrations of condensable vapors according to Kerminen and Kulmala (2002).

\subsubsection{Chemistry}

The sulphur cycle is based on the model by Feichter et al. (1996). The considered gas phase sulphur compounds are dimethylsulfide (DMS), sulphur dioxide $\left(\mathrm{SO}_{2}\right)$ and sulphuric acid $\left(\mathrm{H}_{2} \mathrm{SO}_{4}\right)$.

The prescribed 3-D oxidant fields of $\mathrm{OH}, \mathrm{H}_{2} \mathrm{O}_{2}, \mathrm{NO}_{2}$, and $\mathrm{O}_{3}$ have been calculated with the comprehensive MOZART model by Horowitz et al. (2003). Gas phase DMS and $\mathrm{SO}_{2}$ are oxidised by the hydroxyl radical $(\mathrm{OH})$, and additionally DMS reacts with nitrate radicals $\left(\mathrm{NO}_{3}\right)$. Aqueous phase oxidation of $\mathrm{SO}_{2}$ by $\mathrm{H}_{2} \mathrm{O}_{2}$ and $\mathrm{O}_{3}$ is considered. The aqueous phase concentration of $\mathrm{SO}_{2}$ is calculated using Henry's law accounting for dissolution effects.

Sulphuric acid produced in gas-phase is allowed to condense on existing particles or to nucleate. Sulphate produced in-cloud is distributed into available pre-existing particles in subranges $2 \mathrm{a}$ and $3 \mathrm{a}$. Existing number mixing ratios are used to calculate the fraction of sulphate to insert in a subrange. Within a subrange the mass is distributed evenly into all sections. In case of no pre-existing particles, all of formed sulphate mass is converted into number mixing ratio according to the fixed mean diameter of the size bin and placed in subrange $3 \mathrm{a}$.

\subsubsection{Repartitioning of number and mass concentrations}

In M7, particles are transferred from insoluble to soluble mode when there is a mono-layer coating of soluble material on them (see Vignati et al., 2004). In SALSA, the move requires a predefined fraction of soluble material to condense on the particles before they are transferred to the soluble bin in the same diameter range. The critical soluble fraction for each bin is calculated using Köhler theory with a supersaturation of $0.5 \%$ (Kokkola et al., 2008). While this is implemented in the module, in this study the repartitioning is not used.

In SALSA, the compounds have mass tracers only in subranges 1 and 2, and therefore the growth of particles over the boundary between the 2nd and the 3rd subrange has to be treated separately. When particles grow over the boundary, all mass mixing ratios in $2 \mathrm{a} 4$ are transferred to $3 \mathrm{~b} 1$. The particles from $2 \mathrm{a}$ are transferred to $3 \mathrm{~b}$ since both subranges contain aged particles. The corresponding particle number mixing ratio is calculated from the transferred mass using the fixed bin mean diameter of bin 3b1. Similarly, the mass from insoluble bin $2 \mathrm{~b} 4$ is transferred to bin $3 \mathrm{c} 1$ in case the particles grow across the subrange boundary. The soluble mass fraction from $2 b 4$ is transferred to water soluble fraction of $3 \mathrm{c} 1$.

A more detailed description of SALSA can be found in Kokkola et al. (2008).

\subsection{Removal processes}

\subsubsection{Wet deposition}

Wet deposition is the removal of trace gases and aerosols by clouds and precipitation. Implementation of this process includes re-evaporation and subsequent release of aerosols back to the atmosphere as well as in-cloud and below cloud scavenging. Removal of $\mathrm{SO}_{2}$, DMS and $\mathrm{H}_{2} \mathrm{SO}_{4}$ by precipitation and clouds is calculated using Henry's law (see e.g. Seinfeld and Pandis, 2006).

Activation of aerosols to cloud droplets is not calculated explicitly in the used module version. Instead, their removal from the cloud is parameterized using the solubility of different compounds following Stier et al. (2005). The change of tracer $i$ is calculated with

$$
\frac{\Delta C_{i}}{\Delta t}=\frac{R_{i} C_{i} f^{\mathrm{cl}}}{C_{\text {wat }}}\left(\frac{Q^{\text {liq }}}{f^{\text {liq }}}+\frac{Q^{\text {ice }}}{f^{\text {ice }}}\right),
$$

where $R_{i}$ is a size and composition dependent scavenging parameter for aerosols. $C_{i}$ and $C_{\text {wat }}$ are the mixing ratios of particles and total cloud water, respectively. $f^{\mathrm{cl}}$ is the cloud fraction; $f^{\text {liq }}$ and $f^{\text {ice }}$ are the liquid and ice fractions of cloud water. $Q^{\text {liq }}$ and $Q^{\text {ice }}$ are the respective sums of conversion rates of cloud liquid water and cloud ice water to precipitation through auto-conversion, aggregation and accretion. The calculation is unchanged from Stier et al. (2005), where a more detailed description can be found. The coefficients $R_{i}$ for SALSA are obtained from Stier et al. (2005) and are shown in Table 4. As the coefficients are essentially the same for SALSA and M7, the variations between two aerosol models in wet removal rates for aerosols depend mainly on the simulated cloud patterns.

Aerosols below a precipitating cloud are removed from the atmosphere by rain droplets. Their removal depends on aerosol concentration, collection efficiency and area of precipitation. Largest effect on below cloud scavenging is caused by size dependent collection efficiency of rain and snow, which follows the one presented in Seinfeld and Pandis (2006, see Chapter 20). 
Table 4. Cloud scavenging parameter $R_{i}$ for the subranges of SALSA. The coefficients remain the same for whole subrange, with an exception for smallest size section 1a1.

\begin{tabular}{lllll}
\hline Subrange & $\begin{array}{l}\text { Stratiform } \\
\text { Liquid }\end{array}$ & $\begin{array}{l}\text { Stratiform } \\
\text { Mixed }\end{array}$ & $\begin{array}{l}\text { Stratiform } \\
\text { Ice }\end{array}$ & $\begin{array}{l}\text { Convective } \\
\text { Mixed }\end{array}$ \\
\hline 1a1 & 0.10 & 0.10 & 0.10 & 0.20 \\
$1 \mathrm{a}$ & 0.25 & 0.40 & 0.10 & 0.60 \\
$2 \mathrm{a}$ & 0.85 & 0.75 & 0.10 & 0.99 \\
$\mathrm{2b}$ & 0.20 & 0.10 & 0.10 & 0.20 \\
$3 \mathrm{a}$ & 0.99 & 0.75 & 0.10 & 0.99 \\
$3 \mathrm{~b}$ & 0.40 & 0.40 & 0.10 & 0.40 \\
$3 \mathrm{c}$ & 0.40 & 0.40 & 0.10 & 0.40 \\
\hline
\end{tabular}

\subsubsection{Dry deposition}

Dry deposition velocity is calculated using a serial resistance analogy. The resistance analogy calculates the deposition velocity as inverse of the resistance at the surface $v_{\mathrm{d}}=r^{-1}$, where the resistance $r$ is parameterised from the surface properties according to the scheme of Ganzeveld and Lelieveld (1995) and Ganzeveld et al. (1998). The dry deposition flux is calculated using

$F_{\mathrm{d}}=C \rho_{\mathrm{air}} v_{\mathrm{d}}$

where $C$ is the number mixing ratio, $\rho_{\text {air }}$ is the air density and $v_{\mathrm{d}}$ is the dry deposition velocity. The key obstacle in calculating the dry deposition flux is calculating the deposition velocity, which ties together all relevant processes involved.

For gas-phase compounds, the total apparent resistance at the surface is divided into three parts: aerodynamical $r_{\mathrm{a}}$, quasi-laminar $r_{\mathrm{b}}$ and surface $r_{\mathrm{s}}$ resistances. The aerodynamic resistance $r_{\mathrm{a}}$ is calculated in ECHAM5. The quasi-laminar, or boundary layer, resistance is determined from the kinematic viscosity of the air. The third term, surface resistance, is prescribed for most of the trace gases. Only for $\mathrm{SO}_{2}$, it is calculated using a parameterisation depending on $\mathrm{pH}$, relative humidity, surface temperature and the canopy resistance (Stier et al., 2005). The total resistance is the sum of the three resistances.

In both M7 and SALSA, the calculation of aerosol particle dry deposition uses the big leaf method, with $r=r_{\mathrm{a}}+$ $r_{\mathrm{s}}$. The aerosol deposition is calculated on-line using the aerosol number and mass to calculate the aerosol deposition velocity as a function of particle wet radius, density, turbulence and surface cover, as in Stier et al. (2005). A more detailed description of wet deposition can be found in Kerkweg et al. (2006).

\subsubsection{Sedimentation}

Aerosol particles within the atmosphere are drawn towards the surface by gravitation - this process is known as sedimentation. Sedimentation velocity is calculated using Stokes law (Seinfeld and Pandis, 2006):

$F=\frac{3 \pi \mu R_{\mathrm{p}} U_{\infty}}{C_{\mathrm{c}}}$

where $R_{\mathrm{p}}$ is the particle wet radius, $\mu$ is air viscosity, $U_{\infty}$ is wind velocity and $C_{\mathrm{c}}$ is the Cunningham slip correction factor. The particle radius is assumed equal to the sectional mean radius after the water uptake.

The calculation of sedimentation relies on the radii of the particles, and therefore the deposition velocities for different internally mixed compounds are the same. As the calculated sedimentation velocity might break the Courant-FriedrichLewy stability criterion, the sedimentation velocity is limited to $v \leq \frac{\Delta z}{\Delta t}$, where $\Delta t$ is the timestep length and $\Delta z$ is the model layer thickness.

\subsection{Emissions}

The emission module originally made for M7 has been rewritten for SALSA to produce input suitable for a sectional model, while keeping the emission routines otherwise intact. Sea salt, dust and oceanic DMS emissions are calculated online. For anthropogenic emissions we have used the AeroCom year 2000 emission inventory (Dentener et al., 2006) with modifications by Stier et al. (2005), even though the simulation runs were made using meteorology for year 2008 . As both M7 and SALSA runs have emissions for the same year, this should not cause significant differences between the experiments. However, when comparing to actual observations for year 2008, the emissions from year 2000 may cause discrepancies.

\subsubsection{Carbon emissions}

Carbonaceous particulate emissions are emitted into subranges $1 \mathrm{a}, 2 \mathrm{a}$ or $2 \mathrm{~b}$, assuming lognormal distributions by Stier et al. (2005) with a median particle radius $\bar{r}=0.075$ and standard deviation $\sigma=1.59$ (adapted from the AeroCom distributions by Dentener et al. (2006) which have $\bar{r}=0.04$ and $\sigma=1.8$ ).

There are three different emission sources for black carbon: biofuel, wildfire, and fossil fuel. Black carbon is assumed insoluble, and as such it is emitted to sections within subrange $2 b$ only.

For organic carbon there are four different sources: biogenic, vegetation fire, biofuel and fossil fuel. The portion $65 \%$ of biomass burning (biofuel and vegetation fire) is assumed to be water soluble (Mayol-Bracero et al., 2002) and emitted to subranges 1a or 2a. This organic carbon is mostly emitted through vegetation fires. The remaining $35 \%$ is emitted as insoluble particles to subrange $2 b$. The biogenic emissions are emitted as water soluble particles into subrange $2 \mathrm{a}$ and emissions from the fossil fuel emissions are assumed totally insoluble and emitted to subrange $2 b$. 


\subsubsection{Sulphur emissions}

Sulphur is emitted to the atmosphere mainly as $\mathrm{SO}_{2}$ from natural and anthropogenic sources. Sulphur is naturally emitted to the atmosphere mainly by continuous and explosive volcanic activity, and as dimethylsulfide emitted from both oceanic and terrestrial sources. Anthropogenic sources of $\mathrm{SO}_{2}$ include wild fires, fossil fuel and biofuel.

Emissions from volcanic sources are based on GEIA inventory (http://www.igac.noaa.gov/newsletter/22/sulfur.php; http://www.geiacenter.org/) (Andres and Kasgnoc, 1998). Most of the anthropogenic sulphur $-97.5 \%$ - is emitted as $\mathrm{SO}_{2}$ and $2.5 \%$ is emitted as particulate matter $\mathrm{SO}_{4}$ (Dentener et al., 2006). In the standard version of SALSA, the primary particles are emitted to subranges 1a, $2 \mathrm{a}$ and $3 \mathrm{~b}$ following the modal structure published by Dentener et al. (2006). However, to facilitate the comparison to M7, the primary emissions are in this study described using the M7 modal parameters (Stier et al., 2005).

Sulphur is emitted to the second lowest model level. Original $1 \times 1^{\circ}$ gridded data are remapped to model resolution $1.9 \times 1.9^{\circ}$ using area-weighted averaging.

Emissions of oceanic DMS are calculated on-line by using the Nightingale et al. (2000) parameterisation for air-sea exchange transfer velocities and simulated $10 \mathrm{~m}$ wind speeds. Continental DMS emissions are prescribed as reported by Pham et al. (1995).

\subsubsection{Sea salt emissions}

The sea salt emission scheme has been modified compared to the M7 and therefore we provide a more detailed description of these emissions.

Sea spray droplets are produced by mechanical tearing of waves or by bursting of bubbles at the sea surface (e.g. de Leeuw et al., 2011). These mechanisms can be expressed with several different sea spray generation functions that can be found in the literature. Usually these formulae provide a parameterisation of the emission flux as a function of $10 \mathrm{~m}$ wind speed. Guelle et al. (2001) estimate that the formulation of Monahan et al. (1986) is best suited for small particle range $\left(r_{\text {dry }}\right.$ below $\left.4 \mu \mathrm{m}\right)$. However, Gong (2003) estimate that for particles under $0.2 \mu \mathrm{m}$ radius, the Monahan et al. (1986) parameterisation overestimates the number flux, and thus they formulated a new parameterisation for these small particles. For particles with dry radius above $4 \mu \mathrm{m}$ and below $18.75 \mu \mathrm{m}$, we have used the Andreas (1998) formulation. We calculate the emission flux into 2nd and 3rd subranges, and hence we use the combination of all three parameterisations mentioned above. In the following formulae, $r$ stands for radius at RH $80 \%$, and dry particle mass flux is calculated with $r_{\text {dry }}=0.5 r_{80}$. For radii between $50 \mathrm{~nm}$ to $400 \mathrm{~nm}$, the mass fluxes are calculated using the Gong (2003) parameterisation

$$
\begin{aligned}
& \frac{d F}{\mathrm{~d} r}=1.373 U_{10}^{3.41} r^{-A}\left(1+0.057 r^{3.45}\right) 10^{1.607 \mathrm{e}^{-B^{2}}}, \\
& \quad \text { when } 0.05 \mu \mathrm{m} \leq r \leq 0.4 \mu \mathrm{m},
\end{aligned}
$$

where $A=4.7(1+\Theta r)^{-0.017 r^{-1.44}}$ and $B=(0.433-$ $\log r) / 0.433$. $\Theta$ is a fitting parameter that can be used to adjust the emissions below $0.2 \mu \mathrm{m}$. $U_{10}$ is the windspeed at $10 \mathrm{~m}$ height. According to Gong (2003), changing the parameter $\Theta$ from 30 to 15 can increase the number concentrations as much as one order of magnitude and values 30-40 produce similar emissions. Hence, we have used $\Theta=30$, which will cause underestimation rather than overestimation.

In the $400 \mathrm{~nm}$ to $8 \mu \mathrm{m}$ range, the mass flux is calculated using the Monahan et al. (1986) formulation

$$
\begin{aligned}
& \frac{d F}{\mathrm{~d} r}=1.373 U_{10}^{3.41} r^{-3}\left(1+0.057 r^{1.05}\right) 10^{1.19 \mathrm{e}^{-B^{2}}}, \\
& \quad \text { when } 0.4 \mu \mathrm{m} \leq r \leq 8 \mu \mathrm{m}, \\
& \text { where } B=(0.380-\log r) / 0.650 .
\end{aligned}
$$

For the largest particles with radii over $8 \mu \mathrm{m}$, we use the Andreas (1998) parameterisation

$\frac{d F}{\mathrm{~d} r}=C U_{10} r^{-1}, \quad$ when $r \geq 8 \mu \mathrm{m}$,

where the parameter $C$ is calculated from the boundary condition that Eq. (7) at its upper limit must equal with Eq. (8) at its lower limit.

Following these parameterisations we calculate the number and mass fluxes using $10 \mathrm{~m}$ wind speeds in the range from 0 to $32 \mathrm{~m} \mathrm{~s}^{-1}$. The fluxes are calculated by integrating over each section separately. The number flux within a section is calculated from the mass flux using the sectional mean diameter.

\subsubsection{Dust emissions}

Mineral dust is found throughout the atmosphere either as fine grained silt or as coarse grained minerals and is lifted to the atmosphere by the surface winds. Higher wind speeds increase the amount and also the size of emitted dust particles.

Dust emissions are calculated online using the parameterisation by Tegen et al. (2002). Dust flux is calculated online using $10 \mathrm{~m}$ wind speeds, soil clay content and soil moisture from ECHAM5. Both SALSA and M7 use the same parameterisation. The Tegen et al. (2002) parameterisation gives the flux in sectional space, which is then mapped to M7 modal structure. To produce minimal differences between the models, we use the M7 modal formulation of the flux, which is then mapped to SALSA sections. In SALSA, mineral dust is emitted to subranges $2 \mathrm{~b}$ and $3 \mathrm{c}$.

\subsection{Radiation}

Calculation of aerosol optical properties is computationally very expensive and it is therefore unfeasible to do it online. 
Table 5. Complex refractive indices by compound at $\lambda=550 \mathrm{~nm}$.

\begin{tabular}{lll}
\hline Species & Refractive index & Reference \\
\hline Black Carbon & $1.85+7.1 \times 10^{-1}$ & Hess et al. (1998) \\
Organic & $1.53+5.5 \times 10^{-3}$ & Hess et al. (1998) \\
Sulphate & $1.43+1.0 \times 10^{-8}$ & Koepke et al. (1997) \\
Sea salt & $1.49+1.0 \times 10^{-8}$ & Shettle and Fenn (1979) \\
Dust & $1.52+1.1 \times 10^{-3}$ & Kinne et al. (2003) \\
Water & $1.33+2.0 \times 10^{-7}$ & Downing and Williams (1975) \\
\hline
\end{tabular}

Instead, the needed aerosol properties have been calculated beforehand for 24 spectral bands, as shown by Toon and Ackerman (1981). These precalculated values are provided for ECHAM5-HAM as lookup tables with three dimensions: Mie parameter $\alpha=2 \pi r / \lambda$, and the real and imaginary refractive indices $n_{\mathrm{r}}$ and $n_{i}$. For the Mie parameter, $r$ is the mean radius of a section and $\lambda$ is the wavelength. The compound specific complex refractive indices $n_{\mathrm{r}}$ and $n_{i}$ are shown in Table 5.

Each model bin can have varying mixing ratios of different chemical compounds. Therefore, we approximate $n_{\mathrm{r}}$ and $n_{i}$ by volume-weighted average of the refractive indices of individual compounds including aerosol water. As reported by Lesins et al. (2002), the error in AOD when using this volume-weighted approach can reach up to $15 \%$ in the extreme case of black carbon and water.

From the lookup tables the module retrieves the extinction cross section, single scattering albedo and asymmetry factor. Using these values, the aerosol optical depth and Angström exponent are then calculated for each bin at each grid point.

\section{Comparison to previous model studies}

\subsection{Budgets of aerosol species}

Aerosol budgets and lifetimes give us an overview of the cycling of different compounds. The compound-specific global aerosol budget varies both spatially and temporally.

We have compared the simulated global budget of aerosols between SALSA and M7. To put the results in a context, we have also provided corresponding values reported by Liu et al. (2005b) and Textor et al. (2006). As Textor et al. (2006) focus on particulate species, we have also included results from the Liu et al. (2005b) for reference for the gaseous species within the sulphur cycle. The overview of aerosol lifecycles is presented in Tables 6 and 7. Table 6 summarises the global sulphur cycle for ECHAM5-HAM with SALSA and $\mathrm{M} 7$ and Table 7 summarises the aerosol budget for black carbon, organic carbon, sea salt and dust.

\subsubsection{Sulphur}

Overall, the burdens of sulphur compounds (Table 6) are very similar to those for SALSA and M7. The simulated burden of particulate $\mathrm{SO}_{4}$ is the same with SALSA and M7 at $0.64 \mathrm{Tg}(\mathrm{S})$. This value is only $0.02 \mathrm{Tg}(3.0 \%)$ smaller than the one reported in the AeroCom comparison where the mean for 16 models is $1.99 \mathrm{Tg}\left(\mathrm{SO}_{4}\right)$, which corresponds to $0.66 \mathrm{Tg}(\mathrm{S})$ (Textor et al., 2006, see Table 10.). SALSA shows four times higher mass of nucleated $\mathrm{SO}_{4}$ than M7. This is mostly explained by the model structure. In SALSA the nucleated mass of sulphur includes also the sulphur consumed by growth of freshly nucleated particles from approximately $1 \mathrm{~nm}$ to $3 \mathrm{~nm}$ in diameter.

For the particulate $\mathrm{SO}_{4}$ the difference between the models is caused mainly by aqueous chemistry, a process in which $\mathrm{SO}_{2}$ is oxidised in clouds to produce particulate $\mathrm{SO}_{4}$. Additionally there are small differences in condensation, which contributes roughly one quarter of the particulate phase sulphur. The contribution of condensation is only $0.62 \mathrm{Tg} \mathrm{yr}^{-1}(2.7 \%)$ higher with SALSA than with M7. While the pathways to particulate $\mathrm{SO}_{4}$ are clearly different, the global average burdens for $\mathrm{SO}_{4}$ particles are the same with both models. As for the removal processes, dry deposition of $\mathrm{SO}_{4}$ with both SALSA and M7 is lower than reported by either Liu et al. (2005b) or AeroCom. On the other hand, wet deposition with SALSA is at the upper bound of and with M7 higher than the model spread reported by Liu et al. (2005b). Despite these mismatches in the removal processes between SALSA and earlier studies, the total burden is almost the same as in the AeroCom comparison and within the variation of Liu et al. (2005b). The lower sources therefore seem to be compensated with lower sinks.

The overall burden of sulphur associated with gas phase $\mathrm{H}_{2} \mathrm{SO}_{4} 7 \times 10^{-4} \mathrm{Tg}$ is $22 \%$ smaller than with M7. This difference is caused by differences in sources and sinks. While M7 uses all the available $\mathrm{H}_{2} \mathrm{SO}_{4}$ for condensation and nucleation, in SALSA the amount depends on the equilibrium mass transfer between particles and gas phase $\mathrm{H}_{2} \mathrm{SO}_{4}$.

Using SALSA, the burden of $\mathrm{SO}_{2}$ is $0.23 \mathrm{Tg}(26.4 \%)$ lower than with $\mathrm{M} 7$, but $0.03 \mathrm{Tg}(5.0 \%)$ higher than the maximum burden reported by Liu et al. (2005b). The aqueous oxidation from $\mathrm{SO}_{2}$ to particulate $\mathrm{SO}_{4}$ is $11.41 \mathrm{Tg}(19.0 \%)$ lower with SALSA than with M7. Differences in aqueous oxidation, however, are probably caused by differences in the low-level cloud cover between the model runs (see the cloud cover in Table 6) and do not necessarily indicate differences induced by the different microphysics. Cloud cover of low level clouds (below $750 \mathrm{hPa}$ ) for SALSA run is 2 percentage points lower than with $\mathrm{M} 7$, which causes lower aqueous oxidation of $\mathrm{SO}_{2}$ (see the cloud cover in Table 6). The oxidation of $\mathrm{SO}_{2}$ with $\mathrm{OH}$ is clearly $(51.6 \%)$ higher with SALSA than with any of the models included in the study by Liu et al. (2005b). This may be a result from inefficient wet and dry deposition of $\mathrm{SO}_{2}(39.7 \%$ and $13.5 \%$ lower than with M7), which are at the low end of variation reported by Liu et al. (2005b). The produced $\mathrm{H}_{2} \mathrm{SO}_{4}$ might be overestimated as a result of high oxidation of $\mathrm{SO}_{2}$ with $\mathrm{OH}$. 
Table 6. Annual mean global sulphur cycle calculated using SALSA and M7 as well as results found in the literature. Additionally, the simulated annual mean cover of low $(1013-750 \mathrm{hPa})$, middle $(740-460 \mathrm{hPa})$ and high $(440-50 \mathrm{hPa})$ clouds is included.

\begin{tabular}{|c|c|c|c|c|}
\hline & SALSA & M7 & Liu et al. (2005b) & $\begin{array}{r}\text { AeroCom } \\
\text { (Textor et al., 2006) }\end{array}$ \\
\hline \multicolumn{5}{|l|}{$\mathrm{SO}_{4}$ particle phase } \\
\hline Burden (Tg S) & 0.64 & 0.64 & $0.53-1.07$ & 0.66 \\
\hline \multicolumn{5}{|l|}{ Sources $\left(\mathrm{Tg} \mathrm{S} \mathrm{yr}^{-1}\right)$} \\
\hline Total & 69.23 & 79.59 & & 59.67 \\
\hline Emissions & 1.77 & 1.77 & $0.0-3.5$ & \\
\hline Condensation & 23.40 & 22.78 & & \\
\hline Nucleation & 0.60 & 0.16 & & \\
\hline Aqueous oxidation & 43.47 & 54.88 & $24.5-57.8$ & \\
\hline Sinks $\left(\operatorname{Tg~S~yr}^{-1}\right)$ & 60.92 & 77.95 & & \\
\hline Wet Deposition & 59.46 & 75.38 & $34.7-61.0$ & 53.0 \\
\hline Dry Deposition & 1.47 & 2.42 & $3.9-18.0$ & 7.23 \\
\hline Sedimentation & 0.002 & 0.15 & & \\
\hline Lifetime (days) & 3.61 & 2.92 & & 4.12 \\
\hline \multicolumn{5}{|l|}{$\mathrm{H}_{2} \mathrm{SO}_{4}$ gas phase } \\
\hline Burden (Tg S) & 0.0007 & 0.0009 & & \\
\hline \multicolumn{5}{|l|}{ Sources $\left(\mathrm{Tg} \mathrm{S} \mathrm{yr}^{-1}\right)$} \\
\hline Total & 27.88 & 23.06 & & \\
\hline $\mathrm{SO}_{2}+\mathrm{OH}$ & 25.47 & 20.41 & & \\
\hline $\mathrm{DMS}+\mathrm{OH}$ & 2.41 & 2.65 & & \\
\hline \multicolumn{5}{|l|}{ Sinks $\left(\operatorname{Tg~S~yr}^{-1}\right)$} \\
\hline Total & 24.07 & 23.01 & & \\
\hline Wet Deposition & 0.064 & 0.048 & & \\
\hline Dry Deposition & 0.017 & 0.024 & & \\
\hline Condensation & 23.40 & 22.78 & & \\
\hline Nucleation & 0.60 & 0.16 & & \\
\hline Lifetime (minutes) & 14.11 & 20.16 & & \\
\hline \multicolumn{5}{|l|}{$\mathrm{SO}_{2}$} \\
\hline Burden $(\mathrm{Tg} \mathrm{S})$ & 0.64 & 0.87 & $0.20-0.61$ & \\
\hline \multicolumn{5}{|l|}{ Sources $\left(\operatorname{Tg~S~yr}^{-1}\right)$} \\
\hline Total & 92.10 & 94.75 & & \\
\hline Emissions & 71.03 & 71.03 & & \\
\hline $\mathrm{DMS}+\mathrm{NO}_{3}$ & 4.86 & 5.39 & & \\
\hline $\mathrm{DMS}+\mathrm{OH}$ & 16.21 & 18.34 & & \\
\hline \multicolumn{5}{|l|}{ Sinks $\left(\mathrm{Tg} \mathrm{S} \mathrm{yr}^{-1}\right)$} \\
\hline Total & 89.98 & 93.22 & & \\
\hline Wet Deposition & 3.66 & 2.62 & $0.0-19.9$ & \\
\hline Dry Deposition & 17.38 & 15.32 & $16.0-55.0$ & \\
\hline $\mathrm{SO}_{2}+\mathrm{OH}$ & 25.47 & 20.41 & $6.1-16.8$ & \\
\hline Aqueous oxidation & 43.47 & 54.88 & $24.5-57.8$ & \\
\hline Lifetime (days) & 2.55 & 1.96 & $0.6-2.6$ & \\
\hline \multicolumn{5}{|l|}{ DMS } \\
\hline Burden $(\operatorname{Tg} S)$ & 0.08 & 0.09 & $0.02-3.0$ & \\
\hline \multicolumn{5}{|l|}{ Sources $\left(\operatorname{Tg~S~yr}^{-1}\right)$} \\
\hline Total & 23.46 & 26.37 & $10.7-23.7$ & \\
\hline \multicolumn{5}{|l|}{ Sinks $\left(\operatorname{Tg~S~yr}^{-1}\right)$} \\
\hline Total & 23.48 & 26.38 & & \\
\hline $\mathrm{DMS}+\mathrm{NO}_{3}$ & 4.86 & 5.39 & & \\
\hline $\mathrm{DMS}+\mathrm{OH}$ & 18.62 & 21.00 & & \\
\hline Lifetime (days) & 1.21 & 1.21 & $0.5-3.0$ & \\
\hline \multicolumn{5}{|l|}{ Cloud cover } \\
\hline Low clouds & 0.17 & 0.19 & & \\
\hline Mid clouds & 0.17 & 0.15 & & \\
\hline High clouds & 0.24 & 0.24 & & \\
\hline
\end{tabular}


Table 7. Annual mean global black carbon, organic carbon, sea salt and dust budgets calculated using SALSA and M7 together with budgets found in the literature. For Liu and AeroCom, sedimentation is included in dry deposition.

\begin{tabular}{|c|c|c|c|c|}
\hline & SALSA & M7 & Liu et al. (2005b) & $\begin{array}{l}\text { AeroCom multimodel mean } \\
\text { (Textor et al., 2006) }\end{array}$ \\
\hline \multicolumn{5}{|l|}{ Black carbon } \\
\hline Burden (Tg) & 0.07 & 0.10 & $0.12-0.29$ & 0.24 \\
\hline \multicolumn{5}{|l|}{ Sources $\left(\mathrm{Tg} \mathrm{yr}^{-1}\right)$} \\
\hline Emissions & 7.71 & 7.71 & & 11.90 \\
\hline Sinks $\left(\mathrm{Tg} \mathrm{yr}^{-1}\right)$ & 3.56 & 7.77 & & 13.14 \\
\hline Wet deposition & 3.08 & 7.14 & $7.8-13.7$ & 10.51 \\
\hline Dry deposition & 0.47 & 0.61 & $1.6-4.6$ & 2.63 \\
\hline Sedimentation & 0.008 & 0.02 & & \\
\hline Lifetime (days) & 3.84 & 4.96 & $3.3-8.4$ & 7.12 \\
\hline \multicolumn{5}{|l|}{ Organic carbon } \\
\hline Burden (Tg) & 0.96 & 0.93 & $0.95-1.8$ & 1.70 \\
\hline \multicolumn{5}{|l|}{ Sources $\left(\mathrm{Tg} \mathrm{yr}^{-1}\right)$} \\
\hline Emissions & 66.13 & 66.13 & & 96.60 \\
\hline Sinks $\left(\operatorname{Tg~yr}^{-1}\right)$ & 54.58 & 66.32 & & 105.49 \\
\hline Wet & 49.88 & 61.16 & & 86.87 \\
\hline Dry Deposition & 4.66 & 4.97 & & 18.62 \\
\hline Sedimentation & 0.044 & 0.19 & & \\
\hline Lifetime (days) & 5.30 & 5.14 & $3.9-8.4$ & 6.54 \\
\hline \multicolumn{5}{|l|}{ Sea salt } \\
\hline Burden (Tg) & 11.73 & 12.56 & $3.41-12.0$ & 7.52 \\
\hline \multicolumn{5}{|l|}{ Sources $\left(\operatorname{Tg~yr}^{-1}\right)$} \\
\hline Emissions & 7429.2 & 6234.8 & $1010-8076$ & 16600.00 \\
\hline Sinks $\left(\mathrm{Tg} \mathrm{yr}^{-1}\right)$ & 7446.5 & 6277.3 & & 13915 \\
\hline Wet Deposition & 3054.6 & 3330.8 & & 2168 \\
\hline Dry Deposition & 1693.4 & 1328.0 & & 11747 \\
\hline Sedimentation & 2698.5 & 1618.5 & & \\
\hline Lifetime (days) & 0.58 & 0.74 & $0.19-0.99$ & 0.48 \\
\hline \multicolumn{5}{|l|}{ Dust } \\
\hline Burden (Tg) & 13.11 & 19.3 & $4.3-35.9$ & 19.20 \\
\hline \multicolumn{5}{|l|}{ Sources $\left(\mathrm{Tg} \mathrm{yr}^{-1}\right)$} \\
\hline Emissions & 720.4 & 1603.4 & $820-5102$ & 1840.0 \\
\hline Sinks $\left({\left.\operatorname{Tg~} \mathrm{yr}^{-1}\right)}^{-1}\right.$ & 937.7 & 1649.3 & & 2172.48 \\
\hline Wet Deposition & 439.9 & 961.8 & $486-4080$ & 560.64 \\
\hline Dry Deposition & 106.4 & 116.3 & $183-1027$ & 1611.84 \\
\hline Sedimentation & 391.5 & 517.1 & & \\
\hline Lifetime (days) & 6.64 & 4.39 & $1.9-7.1$ & 4.14 \\
\hline \multicolumn{5}{|c|}{ Water soluble fraction in $3 \mathrm{c}$} \\
\hline Burden (Tg) & 0.0087 & N/A & & \\
\hline \multicolumn{5}{|l|}{ Sources $\left(\operatorname{Tg~yr}^{-1}\right)$} \\
\hline Emissions & N/A & & & \\
\hline Sinks $\left(\operatorname{Tg~yr}^{-1}\right)$ & 0.32 & & & \\
\hline Wet Deposition & 0.26 & & & \\
\hline Dry Deposition & 0.016 & & & \\
\hline Sedimentation & 0.046 & & & \\
\hline Lifetime (days) & & & & \\
\hline
\end{tabular}


Despite the nudging method, the global annual mean $10 \mathrm{~m}$ wind speeds are $4 \%$ lower with SALSA than with M7, which causes $11 \%$ lower emissions of DMS with SALSA. As DMS is globally a large source of sulphur, lower DMS leads to slightly lower mass of $\mathrm{SO}_{2}$ and $\mathrm{SO}_{4}$. However, the emissions with SALSA are at the upper bound of the variation in the emission of DMS as reported by Liu et al. (2005b).

\subsubsection{Organic carbon}

As the prescribed emissions of organic carbon are the same for SALSA and M7, there is no difference between the models in this respect. The atmospheric burden of organic carbon (OC) at $0.96 \mathrm{Tg}$ differs by only $0.03 \mathrm{Tg}(3 \%)$ from the burden simulated with M7 $(0.93 \mathrm{Tg})$. As the organic carbon mass in SALSA is associated only with subranges 1 and 2, the close agreeement between the models suggests that most of the OC is in particles below $700 \mu \mathrm{m}$ in diameter also in M7. In the AeroCom comparison the mean of particulate organic matter is found to be $1.7 \mathrm{Tg}$, which corresponds to $1.21 \mathrm{Tg}$ (OC) being $21 \%$ higher than with SALSA. While the burden is practically the same for M7 and SALSA, the $20 \%$ $(11.55 \mathrm{Tg})$ lower removal of organic carbon in SALSA indicates that part of the mass is transferred to subrange 3 where it is not explicitly tracked and thus implies that the burden should be even little higher with SALSA. This is also seen in SALSA as lower sedimentation of organic carbon particles, which mainly affects very large aerosols. The loss by sedimentation is 2.5 times smaller because only sedimentation of OC is tracked only for particles under $700 \mathrm{~nm}$. In comparison to observations, organic carbon mass is underestimated in most global aerosol-climate models (Jathar et al., 2011) and we would expect to the same for SALSA.

\subsubsection{Black carbon}

Similarly to organic carbon the emissions of black carbon are the same with both models. The burden of black carbon in SALSA is $0.07 \mathrm{Tg}$ which is $0.03 \mathrm{Tg}$ lower than that of M7. Both models simulate a lower burden than any of the studies mentioned by Liu et al. (2005b) and clearly lower than the mean of the models participating in the AeroCom intercomparison. However, even in the AeroCom comparison ECHAM5-HAM had the lowest BC burden of all models which is probably due to lower emissions of carbonaceous material than in the other models. Similarly to organic carbon the removal of black carbon is lower in SALSA than in M7 being less than half of the emitted mass. Removal being clearly lower than emissions implies that a relatively large portion of particles containing $\mathrm{BC}$ are grown to subrange 3 and the actual burden might be within the variation reported by Liu et al. (2005b). The growth of black carbon to 3rd subrange is partly caused by a low removal of insoluble particles by wet deposition thereby increasing the time for growth of particles.

\subsubsection{Sea salt and mineral dust}

A large portion of the mass of sea salt and mineral dust is in particles larger than $700 \mathrm{~nm}$ in diameter. The mass of particles in this size range is estimated using the mean diameter of particles and their densities.

Sources for sea salt are significantly higher with SALSA than with M7 which is caused by the new formulation of sea salt emissions while differences in wind patterns may also play a role. The latter cause is evident especially in the Southern Ocean. Despite the $1200 \mathrm{Tg}$ difference for the emission of sea salt particles, the burden is only $0.83 \mathrm{Tg}(6.6 \%)$ smaller with SALSA. However, the sedimentation is $66 \%$ higher with SALSA. Contributions of dry and wet depositions are of similar magnitude (within $9 \%$ and $22 \%$ respectively) in both models. It seems that the large difference in emissions is compensated by larger sedimentation with SALSA.

For dust, however, emission and burden are clearly lower with SALSA than with M7. The emissions with SALSA are less than half $(44 \%)$ of the emissions with M7. SALSA emissions are similarly less than half of the amount reported in the AeroCom emission inventory (Dentener et al., 2006). The difference is caused by $7 \%$ lower surface wind speeds over land with SALSA and the calculation of emissions using modal parameters for SALSA sectional structure. Dry removal processes are still quite comparable $(9 \%$ lower in SALSA), and the main difference in the total removal rate is due to wet deposition. In SALSA mineral dust is mainly emitted to insoluble sections and therefore has a weaker wet deposition flux. Also the removal by dry deposition and sedimentation is low especially when comparing with AeroCom comparison. This might be influenced by fixed sectional diameters in the sub region 3 as sedimentation velocity is strongly dependent on the particle diameter.

The water soluble fraction in the subrange $3 \mathrm{c}$ constitutes a very small part of total aerosol loading. Global burden is only $0.0087 \mathrm{Tg}$ which is in the same range as for gas phase $\mathrm{H}_{2} \mathrm{SO}_{4}$.

\subsection{Lifetimes}

We calculated the lifetime of particles by using a relation between source and burden rather than sink and burden. We chose this way because part of the aerosol mass is transferred to subrange 3 which does not include mass tracers. However, there will be some error because the burden does not include particles larger than $700 \mathrm{~nm}$ in diameter for $\mathrm{OC}, \mathrm{BC}$ and $\mathrm{SO}_{4}$.

The lifetimes of black carbon and sea salt are shorter with SALSA than with M7, but otherwise M7 predicts shorter lifetimes. For black carbon and dust the difference in lifetimes between models exceeds one day.

Lifetimes for the simulated compounds, with the exception of black carbon are within the variation reported in the AeroCom intercomparison (Textor et al., 2006). In all cases SALSA is within the variation shown in Liu et al. (2005b). 
When comparing to the AeroCom multimodel mean, the largest difference is found for black carbon, which is mostly caused by the coagulation or growth losses to particles larger than $700 \mathrm{~nm}$ in diameter in SALSA. Lower burden and removal by dry and wet deposition and sedimentation than in the other models could indicate that a large fraction of the material is removed by the processes affecting particles grown over the $700 \mathrm{~nm}$ boundary in the aerosol model.

Even though the sea salt emissions are higher, the lifetime of particles is shorter with SALSA than with M7 because the removal rate of sea salt is increased. This increase in removal is mainly due to higher sedimentation in SALSA than in M7, thereby resulting in $21.6 \%$ smaller lifetime than with $\mathrm{M} 7$.

For dust, the lifetime with SALSA is 2.45 days lower than with M7 but the proportional significance of different removal processes are rather consistent with $\mathrm{M} 7$, while the emissions are less than half of those simulated with M7 and little less than in other studies previously reported (Liu et al., 2005b; Textor et al., 2006).

\subsection{Spatial distribution of aerosol mass}

Figure 2 shows the annual mean of vertically integrated column mass of the compounds in particulate phase. Aerosol mass distribution of different compounds varies depending on the properties of the compound, as can be seen in Fig. 2. Removal and transport depends largely on the composition of particles, and particles consisting of mainly water soluble material are more prone to be removed by wet deposition, while fine insoluble particles will more probably be transported further from the source.

Sulphate is seen in large areas over both land and ocean. The wide dispersal of $\mathrm{SO}_{4}$ results from $\mathrm{SO}_{2}$ dispersion throughout the atmosphere and its oxidation to $\mathrm{H}_{2} \mathrm{SO}_{4}$ and consequent nucleation and condensation. Regions with highest burdens for organic carbon coincide with strong emission areas, as most of the global organic carbon is found in the South America and Central Africa. The column burden of sea salt is naturally high over the oceans. However, there are also relatively high burdens in some parts of, e.g. Australia, South-America and East-Coast of Africa, indicating transports inland. Sea salt burden is the highest in the Southern Ocean, which has reportedly very high windspeeds (Yuan, 2004) producing large amounts of sea salt. By comparing sea salt and aerosol water burdens in Fig. 2d and f, we can see that a large part of aerosol water is associated with sea salt aerosols.

Dust burden is highest near large deserts. Most prominently the dust emissions from deserts are seen over Sahara, while also Asian and Australian deserts show large dust burden. The transport of Saharan dust all the way to Amazonia can be seen in the model, a phenomenon that has also been observed by Gilardoni et al. (2011). a)

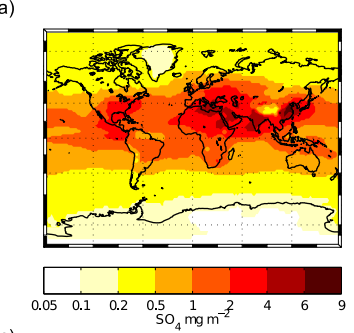

c)

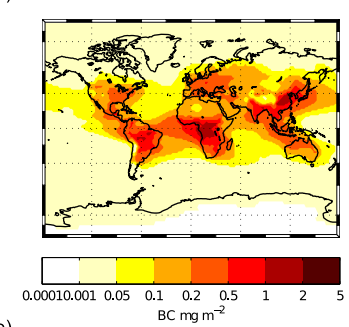

e)

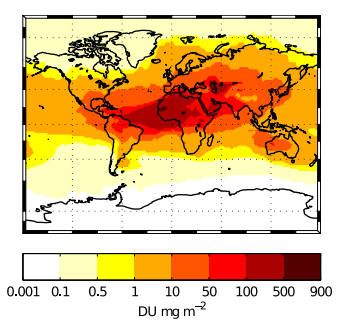

b)
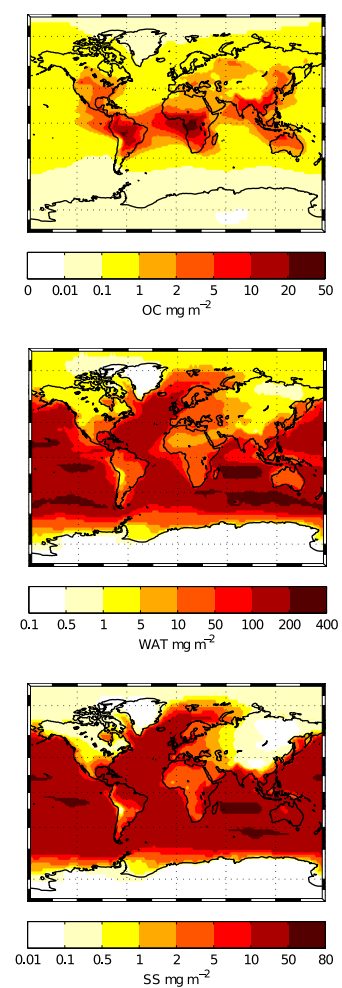

Fig. 2. Annual mean of vertically integrated column mass for year 2008 for (a) sulphate $\left(\mathrm{SO}_{4}\right)$, (b) organic carbon (OC), (c) black carbon (BC), (d) particulate water (WAT), (e) dust (DU) and (f) sea salt (SS) simulated with SALSA. All units are $\mathrm{mg} \mathrm{m}^{-2}$.

\subsection{Vertical distribution}

In Fig. 3 we show the annual mean of the zonally averaged number concentrations for SALSA (left hand panels) and M7 (right hand panels). The M7 number concentrations are calculated for SALSA subrange diameter ranges to facilitate comparison. Additionally, we have plotted the M7 number concentrations of particles below the lower limit of SALSA in the topmost panel on the right hand side.

In Fig. 3a we can see that especially in the upper troposphere, the binary nucleation creates an extremely high amount of particles in M7 that do not show up in SALSA due to their inability to grow over $3 \mathrm{~nm}$ in diameter, which is the low cut-off diameter of SALSA's size distribution.

With M7 the concentrations of particles $3-50 \mathrm{~nm}$ in diameter are between $2000-10000 \mathrm{~cm}^{-3}$ at the maximum, while SALSA has concentrations as much as ten times higher with $10000-50000 \mathrm{~cm}^{-3}$ in the upper troposphere. Additionally, the high concentrations extend to somewhat lower pressures. This difference is caused primarily by different treatment of the smallest particles. In SALSA the sub- $3 \mathrm{~nm}$ particle growth has been parameterised, while M7 has a nucleation mode that extends to this size range. As much of the condensating vapor $\mathrm{H}_{2} \mathrm{SO}_{4}$ is used for nucleation in $\mathrm{M}$, 

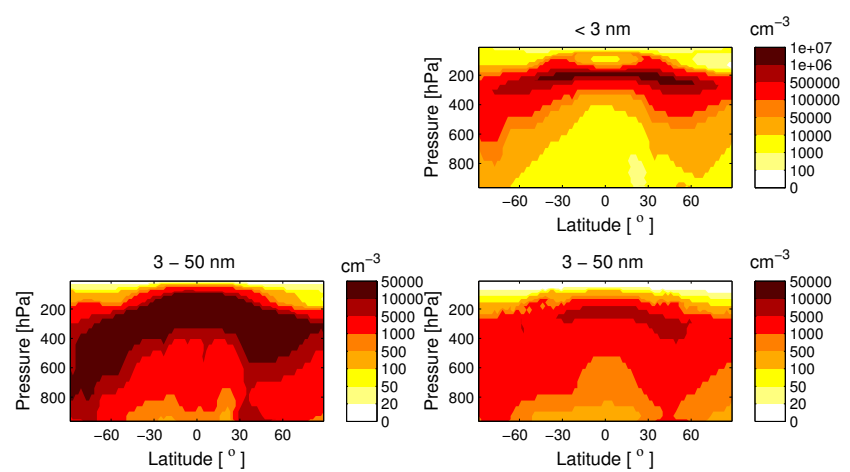

$50-700 \mathrm{~nm}$
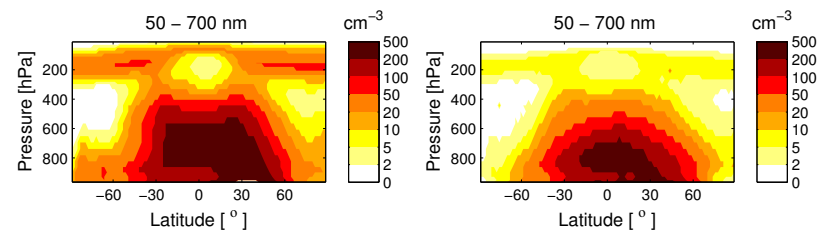

$700 \mathrm{~nm}-10 \mu \mathrm{m}$
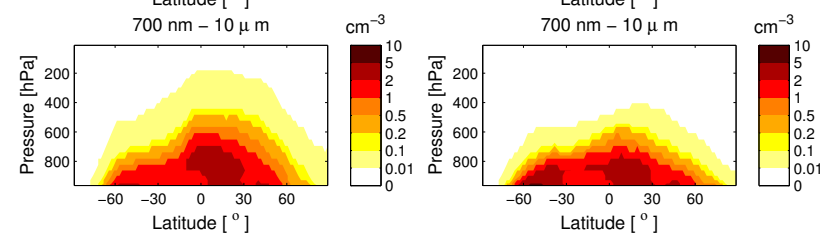

Fig. 3. Annual means of zonally averaged global vertical concentration distribution of particles. Left hand panels show concentrations with SALSA and right hand panels show the M7 concentrations mapped to SALSA subrange structure. Each panel corresponds to one subrange of SALSA: from the top 1, 2, 3. For M7 the topmost panel shows particle concentrations below the $3 \mathrm{~nm}$ lower limit of SALSA.

the particles do not grow enough to show up in the $3-50 \mathrm{~nm}$ range.

In the $200 \mathrm{hPa}$ region of subrange 2 , SALSA has concentrations of $20-100 \mathrm{~cm}^{-3}$ while $\mathrm{M} 7$ has concentrations below $10 \mathrm{~cm}^{-3}$. This difference is probably a result from having four size classes in SALSA and one or two modes with M7, thereby producing more accurate description for removal processes in SALSA than in M7. In addition, with SALSA the particle concentrations in the boundary layer are higher at high latitudes, with concentrations of 20 to $50 \mathrm{~cm}^{-3}$ as compared to 0 to $10 \mathrm{~cm}^{-3}$ with $\mathrm{M} 7$. Near the equator the concentration maximums are closer but SALSA still shows more particles than M7.

In the 3rd subrange the concentrations are relatively similar with both models. However, with SALSA the particles are transported higher and M7 shows slightly higher concentrations in the $200-600 \mathrm{hPa}$ region. In the Southern Hemisphere $\left(60^{\circ} \mathrm{S}\right.$ to $\left.30^{\circ} \mathrm{S}\right)$ the surface concentrations with $\mathrm{M} 7$ are higher in this size range. In this region SALSA shows only $2-5 \mathrm{~cm}^{-3}$ while M7 has values $2-10 \mathrm{~cm}^{-3}$. In this region, most of the particles are sea salt and it seems that in SALSA the sea-salt particles are larger and fewer, which may be caused by the fixed diameters used in the 3rd diameter range.
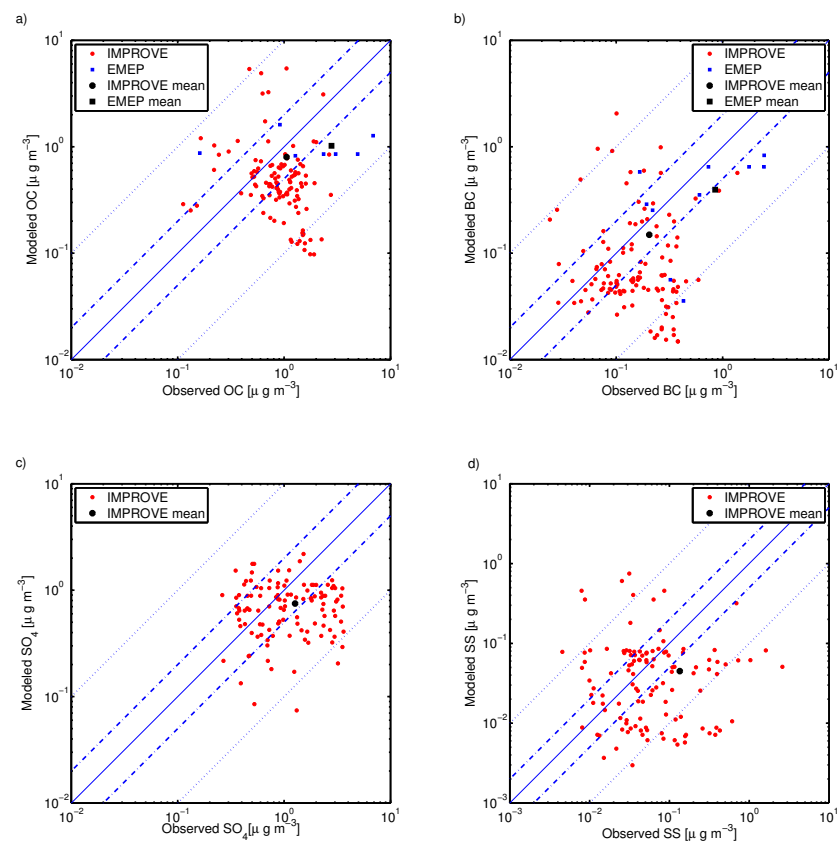

Fig. 4. Scatterplot of simulated and observed annual mean surface concentrations of organic carbon, black carbon, sulphate and sea salt. Red circles indicate comparison with IMPROVE network and blue squares represent EMEP network. Black symbols represent mean values of respective symbols. Solid line indicates 1:1 ratio between observations and simulated values. Similarly dot-dashed line indicates $1: 2$ and 2:1 ratios, and dotted lines indicate $1: 10$ and 10:1 ratios.

\section{Comparison to surface measurements}

\subsection{Surface concentrations of particulate mass}

We have compared the simulated and observed annual mean surface mass concentrations (Fig. 4) of sulphate, organic carbon, black carbon and sea salt at measurement stations of the European Monitoring and Evaluation programme (EMEP; http://www.emep.int) and United States Interagency Monitoring of Protected Visual Environment (IMPROVE; http://vista.cira.colostate.edu/improve/) networks. The scatterplots show the simulated concentrations in the lowest model layer in the gridboxes corresponding to measurement site locations. From the IMPROVE network, we have included data for 169 sites which correspond to 117 different gridpoints. To avoid comparing one gridpoint to more than one observation we have averaged the station data in cases where more than one station corresponds to a single gridpoint. From the EMEP network, we found only 11 sites with data for year 2008 and from these only 7 had data for organic carbon although all 11 had data for black carbon. Sulphate and sea salt concentration data from EMEP stations were not available for year 2008. The observed data corresponds to the mass concentrations of particles of diameter 
lower than $2.5 \mu \mathrm{m}$. The modelled mass concentration of sulphate, organic and black carbon is accounted for particles under $700 \mathrm{~nm}$ in diameter while the modeled mass concentrations of sea salt includes all smaller than $1.7 \mu \mathrm{m}$ in diameter (bins 2a1-3a1). The sea salt size range is chosen to correspond to the PM2.5 data available from the stations. The mean fractional bias (MFB) showing the overall deviation of the modelled concentrations from the observations of the IMPROVE network are shown in Table 8. MFB indicates that performance with SALSA is lower than M7 for organic carbon, while for other species performance is slightly better.

For the organic carbon mass concentrations (Fig. 4a), we can see that SALSA underestimates the surface concentrations. Out of the 117 comparison pairs, $45(36.5 \%)$ are within a factor of two of the IMPROVE network data. On the other hand, in only $12(10.3 \%)$ cases the discrepancy is over one order of magnitude. For EMEP data, the simulated concentrations fall within one order of magnitude at all of the seven sites. For IMPROVE, the mean simulated mass concentrations $\left(0.80 \mu \mathrm{g} \mathrm{m}^{-3}\right)$ is within a factor of two of the observed mean $\left(1.05 \mu \mathrm{g} \mathrm{m}^{-3}\right)$, and for EMEP with a factor of three (simulated $1.02 \mu \mathrm{g} \mathrm{m}^{-3}$, observed $2.79 \mu \mathrm{g} \mathrm{m}^{-3}$ ) M7 shows slightly lower mean concentrations $\left(0.73 \mu \mathrm{g} \mathrm{m}^{-3}\right.$ for IMPROVE and $0.93 \mu \mathrm{g} \mathrm{m}^{-3}$ for EMEP) than SALSA.

The simulated black carbon mass concentration mean (Fig. 4b) for gridpoints corresponding to the IMPROVE sites is $0.15 \mu \mathrm{g} \mathrm{m}^{-3}\left(0.16 \mu \mathrm{g} \mathrm{m}^{-3}\right.$ with M7) which is $23 \%$ lower than the observed mean of $0.20 \mu \mathrm{g} \mathrm{m}^{-3}$. In 43 of the 117 cases $(36.7 \%)$, the simulated concentration is within a factor of two of the observed concentration. There are 17 gridpoints where the concentration differs by more than by a factor of 10 from the observation. Thus, between the IMPROVE sites there is large variation in model performance, while on average the model captures concentrations quite well. The simulated mean of black carbon mass for EMEP sites is $0.39 \mu \mathrm{g} \mathrm{m}^{-3}\left(0.38 \mu \mathrm{g} \mathrm{m}^{-3}\right.$ for M7) underestimating the observed mean of $0.85 \mu \mathrm{g} \mathrm{m}^{-3}$ by $54 \%$. The black carbon budget suggests that the underestimation is partly due to the mass associated with particles with diameter over $700 \mathrm{~nm}$ (Table 7).

In Fig. 4c, the scatterplot for $\mathrm{SO}_{4}$ is shown. In 58 (49.6\%) cases the simulated concentration is within a factor of two of the IMPROVE observations. The mean simulated concentration of $\mathrm{SO}_{4}$ is $0.75 \mu \mathrm{g} \mathrm{m}^{-3}\left(0.66 \mu \mathrm{g} \mathrm{m}^{-3}\right.$ with M7). It is within a factor of two of the mean of observed concentrations $\left(1.27 \mu \mathrm{g} \mathrm{m}^{-3}\right)$. The concentrations exceeding $1 \mu \mathrm{g} \mathrm{m}^{-3}$ are underestimated using SALSA by over one order of magnitude at three gridpoints. However, the modelled sulphate mass is only tracked only up to the diameter of $700 \mathrm{~nm}$ while the observations include particles up to $2.5 \mu \mathrm{m}$ which partly explains the low concentrations.

Both observed and simulated sea-salt mass concentrations (Fig. 4d) exhibit high variation. The simulated concentrations have a mean of $0.045 \mu \mathrm{g} \mathrm{m}^{-3}\left(0.16 \mu \mathrm{g} \mathrm{m}^{-3}\right.$ with M7) underestimating the observed mean of $0.13 \mu \mathrm{g} \mathrm{m}^{-3}$ by $65 \%$ for
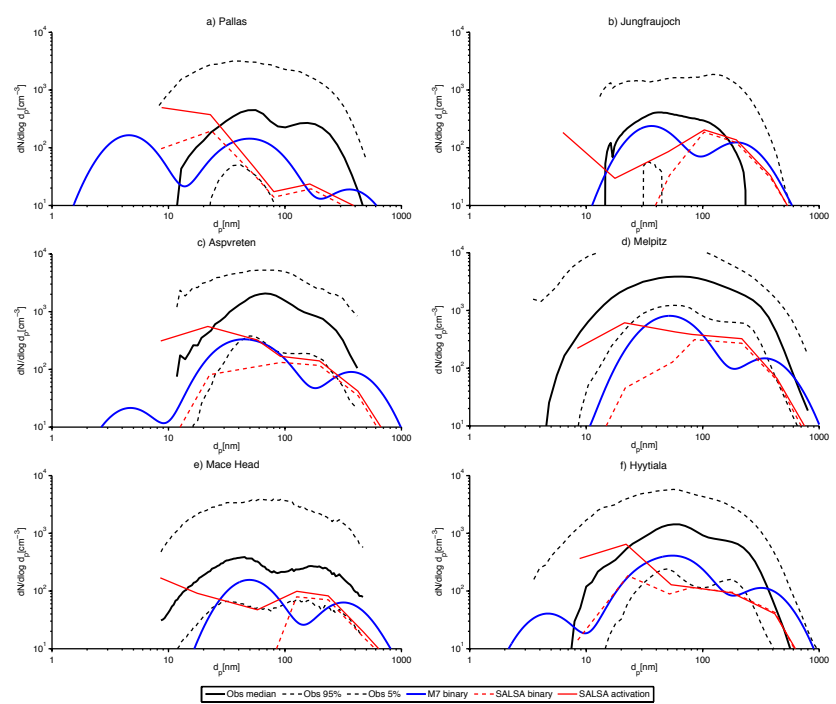

Fig. 5. Observed and simulated annual median size distributions for six measurement stations (a) Pallas, (b) Jungfraujoch, (c) Aspvreten, (d) Melpitz, (e) Mace Head and (f) Hyytiälä. Simulated size distribution for M7 is plotted in blue solid line. Simulated size distributions for SALSA are plotted with red solid line indicating activation type nucleation and with red dashed line for binary nucleation. Observed annual median size distributions are plotted in black, with dashed black lines showing the 95th and 5th percentiles of observed concentrations (Asmi et al., 2011).

Table 8. Simulated mean fractional bias between observations at IMPROVE stations and modelled values with SALSA and M7 for organic carbon, black carbon sulphate and sea salt.

\begin{tabular}{lrr}
\hline & SALSA & M7 \\
\hline $\mathrm{OC}$ & -0.254 & -0.162 \\
$\mathrm{BC}$ & -0.242 & -0.248 \\
$\mathrm{SO}_{4}$ & -0.192 & -0.261 \\
$\mathrm{SS}$ & -0.102 & 0.418 \\
\hline
\end{tabular}

the IMPROVE sites. Out of the 117 cases, only $36(30.8 \%)$ are within a factor of two of the observed concentrations. The discrepancy between the observed and simulated concentrations can be as much as two orders of magnitude. The underestimation in larger particles may be partly due to the coarse sectional structure and partly due to the inadequately described transport to continental sites in the module.

\subsection{Particle size distributions and number concentrations over Europe}

Asmi et al. (2011) have collected aerosol measurement data for European Integrated Project on Aerosol Cloud Climate Air Quality interactions (EUCAARI; Kulmala et al., 2009, 2011) project sites for the year 2008. We have compared 
a subset of these measurements to the size distributions simulated with SALSA and M7. Figure 5 shows the modelled and observed annual median aerosol size distributions at six EUCAARI sites: Jungfraujoch (Jurnyi et al., 2011), Hyytiälä (Hari and Kulmala, 2005), Mace Head (Jennings et al., 1991), Aspvreten (Tunved et al., 2004), Melpitz (Engler et al., 2007) and Pallas (Lihavainen et al., 2008). These sites include coastal (Mace Head), mountain (Jungfraujoch), arctic (Pallas), boreal coniferous (Hyytiälä), urban polluted (Melpitz) and mixed boreal coniferous and deciduous (Aspvreten) locations. For SALSA we have plotted the size distributions from simulations using either binary or activation nucleation mechanisms, while for M7 only binary nucleation mechanism is available.

When the activation-type boundary layer nucleation is used, the concentration of small particles increases. This leads to a better agreement with observations of particles smaller than $50 \mathrm{~nm}$ in diameter than using only binary nucleation, which is in line with earlier studies with activationtype nucleation (e.g. Spracklen et al., 2010; Kazil et al., 2010). The concentrations produced using binary nucleation only in either of the models are significantly lower than observed. At the selected sites, there is little or no difference in the concentrations of particles larger than $80 \mathrm{~nm}$ in diameter between the binary or activation-type nucleation simulations with SALSA. This indicates that the concentrations of particles in this size range depends heavily on the primary emissions and the higher concentrations of small particles with activation-type nucleation do not grow this large. Note that the modelled growth of nucleation mode particles could be increased with the inclusion of organic vapors.

Both SALSA and M7 show similar concentrations when using binary nucleation at four of the six sites. At Jungraujoch and Mace Head the Aitken mode particles have very low concentrations with SALSA, but the concentration is increased when using activation-type nucleation. However, the increased concentrations of these particles have very limited effect on the concentration of particles $50 \mathrm{~nm}-100 \mathrm{~nm}$ in diameter.

In Fig. 5c, $d$ and e we see that the concentrations of particles $100 \mathrm{~nm}$ to $300 \mathrm{~nm}$ in diameter are clearly higher with SALSA than with M7. For this size range, SALSA is closer to the observed concentrations, while it has trouble predicting the concentrations of particles $50 \mathrm{~nm}-100 \mathrm{~nm}$ in diameter, as seen in observations and simulation with M7. This is possibly caused by scavenging of small particles by coagulation and too low condensational growth of smaller particles.

The particles $100 \mathrm{~nm}-500 \mathrm{~nm}$ in diameter contribute most of the cloud condensation nuclei concentration, and therefore this size range is important for cloud activation studies. The cloud activation occurs mainly in diameter range $50 \mathrm{~nm}-$ $200 \mathrm{~nm}$; and compared to M7, SALSA shows better agreement to observations for these particles in polluted regions and worse agreement in regions with clean air. However, the simulated concentrations remain lower than the observed,
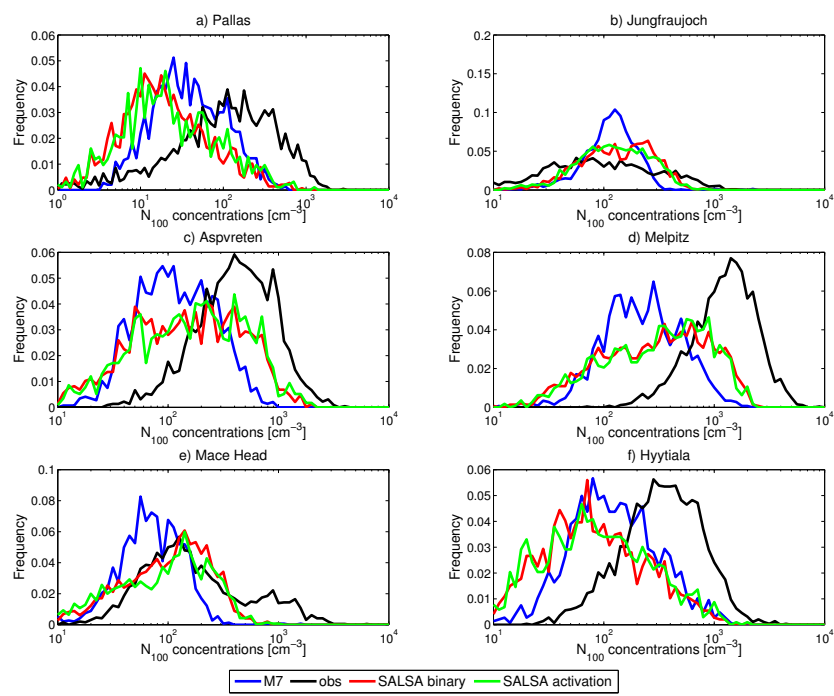

Fig. 6. Histograms of $N_{100}$ concentrations at six EUCAARI stations. The concentration bins are evenly distributed in the logarithmic concentration axes. Y-axis shows the relative fraction of each bin compared to total number of valid measurements.

which is probably mainly caused by the missing condensation of organic vapors which has been shown to have a large impact on the growth of particles in this size range (Riipinen et al., 2011).

Figure 6 shows the histograms of total number concentrations of $100-500 \mathrm{~nm}$ particles $\left(N_{100}\right)$ at six EUCAARI stations. The particle diameter of $100 \mathrm{~nm}$ corresponds roughly to activation at critical supersaturation of $0.3 \%$ for Finnish background aerosol (Sihto et al., 2010). In four cases SALSA shows wider frequency of concentrations, with higher frequencies at the larger concentrations than M7. In Mace Head the high observed concentrations associated with polluted air are not reproduced with either model, while the low concentrations associated with marine air are well reproduced with SALSA (A. Asmi, personal communication, 2011). This supports the good agreement between SALSA and observations for the marine size distributions (Fig. 8). In Pallas and Hyytiälä, M7 shows histograms slightly closer to observed than SALSA, although the histograms with both models are fairly similar. Overall, SALSA seems to reproduce the observed histograms of particles at size range relevant to cloud activation better than $\mathrm{M} 7$, indicating its better applicability to cloud activation studies. However, at sites with cleaner air (Pallas and Hyytiälä), M7 performs better. This further indicates that with too low simulated growth of particles below $50 \mathrm{~nm}$ in diameter, $N_{100}$ depends largely on emissions.

The inclusion of organic vapors should increase the number of particles in diameter range important for cloud activation, especially in clean environments. While both models underestimate the number concentration in the size range relevant for cloud activation, in some cases SALSA performs 


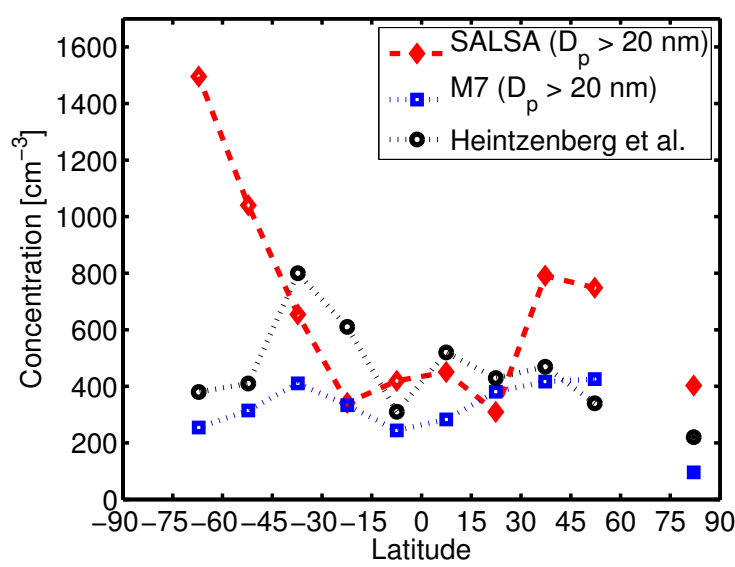

Fig. 7. Total annual mean sea surface concentration of particles in 10 latitude bands. Observed size distributions are marked with black, SALSA with red diamonds and M7 in blue squares. The observed mean values for the latitude bands are shown in black circles. As the observations have a lower cutoff diameter of $20 \mathrm{~nm}$ the modelled concentrations are shown only for particles larger than $20 \mathrm{~nm}$ in diameter.

slightly better than M7 and vice versa. Nevertheless, the effect of organic vapors should be studied before the implementation of cloud activation of particles.

\subsection{Marine particle number size distributions}

Heintzenberg et al. (2000) compiled a data set of marine boundary layer (MBL) aerosol size distributions from three decades of cruise and flight measurements. In their work the size distribution data was presented as log-normal bimodal distribution with a geometric mean diameter, standard deviation and number concentration given on both modes. The distributions have been reported for 10 latitude bands. We have plotted the observed data together with simulated concentrations for SALSA and M7 (Figs. 7 and 8).

Figure 7 shows the average surface concentrations of particles larger than $20 \mathrm{~nm}$ in diameter for 10 different latitude bands. SALSA and M7 concentrations are averaged from the same regions as the observations (Fig. 1 in Heintzenberg et al., 2000). The observed mean values are in the range $370-500 \mathrm{~cm}^{-3}$ while, the simulated values can reach over $1500 \mathrm{~cm}^{-3}$ in the Southern Ocean. In this region we can see the largest discrepancy between the module and the observations as the simulated particle concentrations for SALSA are 4-fold over the observed values.

In the tropics, SALSA and M7 show similar concentrations of particles. In other latitude bands, the concentration with SALSA are higher than those with M7. The largest difference between the models is again seen in the Southern Ocean, where SALSA produces five times higher concentrations of particles larger than $20 \mathrm{~nm}$ in diameter than M7. This difference is seen because the measurement locations between Antarctica and South America used in the comparison coincide with a regions with high concentrations of sulphuric acid. The high amount of sulphuric acid causes stronger growth of freshly formed particles by condensation with SALSA than with $\mathrm{M} 7$, resulting in high concentrations of particles $20 \mathrm{~nm}-50 \mathrm{~nm}$ in diameter. While M7 predicts a mean marine concentration of $320 \mathrm{~cm}^{-3}$ and thus underestimates the observed mean concentration of $450 \mathrm{~cm}^{-3}$, the new sea salt formulation of SALSA causes it to overestimate the number concentrations with mean of $670 \mathrm{~cm}^{-3}$. Despite overpredicting the mean concentration, SALSA mostly shows better agreement with the observations than M7. Furthermore, SALSA captures the concentrations at the roaring fourties $\left(40^{\circ}-49^{\circ} \mathrm{S}\right)$ much better than $\mathrm{M} 7$.

The M7 has lower root mean square error of average number concentrations of 184.0 while SALSA has 225.1. With similar and quite large errors, both M7 and SALSA perform equally well.

Simulated and observed particle size distributions in Fig. 8 are shown for annual mean surface concentrations in 12 latitude bands. For the modelled values we use gridpoints corresponding to the $15^{\circ} \times 15^{\circ}$ gridboxes, as explained by Heintzenberg et al. (2000). Especially for particles 0.01$0.1 \mu \mathrm{m}$ in diameter, SALSA shows worse agreement with observations than M7; for the particles with diameters ranging $0.1-1 \mu \mathrm{m}$, SALSA shows better agreement with the observations than M7.

\section{Comparison to remote sensing observations}

\subsection{Aerosol optical depth}

The simulated aerosol optical depth (AOD) is compared with satellite and ground-based measurements. The satellite retrievals include both the Moderate Resolution Imaging Spectrometer (MODIS) (Remer et al., 2005) and Multi-angle Imaging SpectroRadiometer (MISR) (Martonchik et al., 1998; Kahn et al., 2005) instruments. Because the MODIS AOD over land areas has high uncertainties (Levy et al., 2010; Pinty et al., 2010), we use a composite of the MODIS and the MISR instruments. The MODIS is used for ocean and MISR for land gridpoints. Ground-based measurements are gathered from the AERONET robotic network of sunphotometers (Holben et al., 1998).

MODIS and MISR level 3 data, which have a spatial resolution of $1 \times 1$ degree, were downloaded from NASA's Giovanni (Acker and Leptoukh, 2007) web portal (http://daac. gsfc.nasa.gov/giovanni/). The composite MODIS-MISR annual mean is calculated from monthly mean values.

The globally averaged aerosol optical depth for SALSA run with binary nucleation is 0.08 , which is clearly lower than 0.12 calculated with M7. When calculating the AOD for gridpoints with available MODIS-MISR data, the global annual average for satellite composite is 0.16 . Mean AOD for 

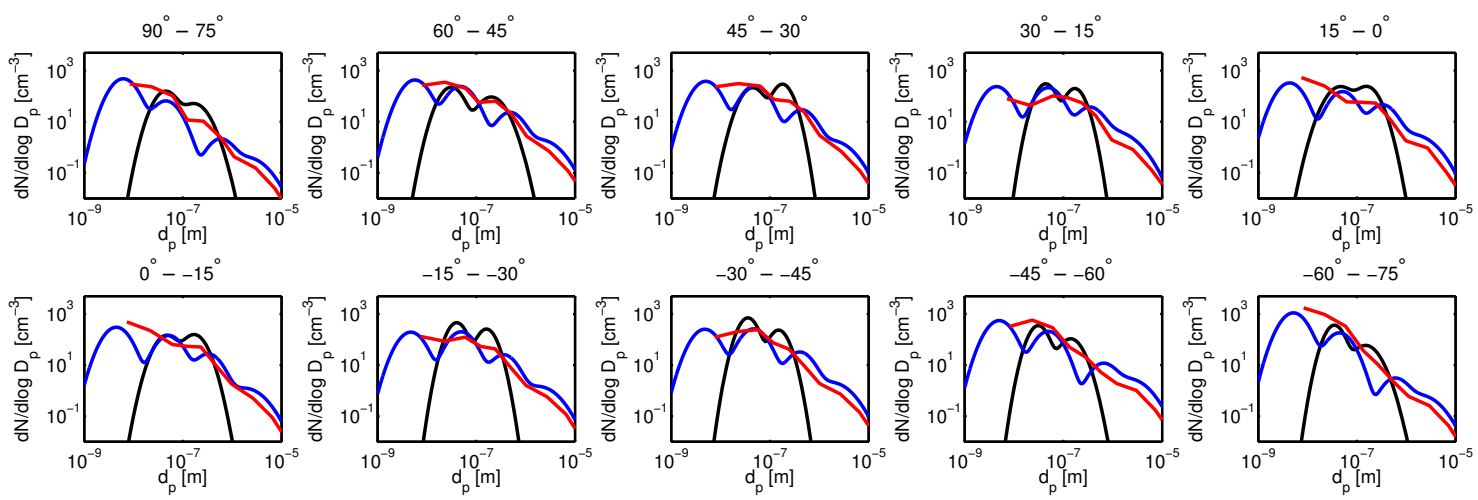

Fig. 8. Annual mean surface size distributions on twelve $15^{\circ}$ latitude bands for SALSA (red), M7 (blue) and observations (black) collected by Heintzenberg et al. (2000). Modeled size distributions have been calculated in the grid points corresponding to the locations of the observations.

gridpoints with satellite composite data is 0.11 with SALSA and 0.15 with M7. While the AOD at high latitudes is approximately the same with both models, the AOD at the tropics is lower with SALSA, resulting with lower global mean AOD.

Figure 9a shows the observed clear sky annual mean aerosol optical depth (AOD) composite of the satellite retrievals. Figure $9 \mathrm{~b}$ shows the difference with SALSA to satellite retrieval, while Fig. 9c has the difference with M7. Although global annual mean aerosol optical depth simulated with SALSA is smaller than satellite retrieval, the spatial distribution is quite good. The AODs over ocean gridpoints in the tropics are generally within 0.02 of the satellite retrieval (Fig. 9). With both models the high latitudes have much lower AOD than satellite retrievals, especially over Siberia in Russia; over Canada and in the coast of Alaska the AOD is underpredicted, with 0.2 smaller values than in MISR retrieval. The AOD is lower probably partly due to old emission inventory (Granier et al., 2011) and partly due to too low transport (Bourgeois and Bey, 2011) from tropics and mid-latitudes towards the poles. Furthermore, MODIS sees a band of higher AOD around Antarctica, which the models do not reproduce. However, the differences in this area are partly caused by the cloud fraction affecting the satellite aerosol retrieval (Shi et al., 2011). Furthermore, in the Saharan dust bloom over North Atlantic Ocean, M7 shows AOD 0.15 higher than observed, while SALSA shows only 0.02 difference to the observed AOD (Fig. 9). In Europe and the east coast of the USA, the AOD with SALSA is captured mainly within 0.02 of the observed while M7 shows differences over 0.05 .

In a sensitivity test we found that when replacing the M7 modal standard deviations with those suggested by Dentener et al. (2006) (see Sect. 2.6.1), the AOD between Africa and South America increased at most by 0.02 (not shown). However, this results only in 0.001 increase on the global annual mean AOD. Similarly, activation-type nucleation has no effect on the AOD despite the increase in $50 \mathrm{~nm}$ particles. This is expected because their effect on the concentration of particles larger than $200 \mathrm{~nm}$ is very low (see Fig. 5).

Even though M7 is in a better agreement in terms of global average AOD, this is because underprediction of M7 at high-latitudes is compensated by overprediction over tropical oceans. The underprediction at high-latitudes is seen with both models and is probably due to low transport of aerosols towards the poles, as stated earlier. The low transport of aerosols to polar regions is a well documented problem with several global aerosol models (Shindell et al., 2008; Koch et al., 2009; Korhonen et al., 2008).

In Fig. 10, we show the AERONET (Holben et al., 2001) robotic network level 2 data for AOD for 42 sites with monthly mean data for 2008 . The simulated data are plotted as box plots against five observed AOD ranges. SALSA shows somewhat lower variation compared to M7 with a lower median in all ranges. The AOD at AERONET sites is mainly below 0.3 , and for these occurrences both models show mostly AODs within the range. In the smallest range from 0.0 to 0.1, SALSA is underestimating slightly less than M7. For the AOD from 0.1 to 0.2 , SALSA is underestimating and having lower extreme values compared to M7. In all three smallest AOD classes where the observed AOD is under 0.3, the median for SALSA is 0.10, which is lower than AERONET AOD of 0.12, and lower than M7 AOD, which is equal to 0.14. Both models underestimate the observed values exceeding 0.3. Usually the high AODs correspond to extreme events such as dust blooms and are often underpredicted in global models. However, the most frequent small AODs are reproduced relatively accurately.

\section{2 Ångström exponent}

Figure 11 shows the Ångström exponent over oceans for SALSA, M7 and MODIS. The uncertainty of MODIS instrument is large over land (Mielonen et al., 2011) and therefore we have included the Ångström exponent only over oceans. 

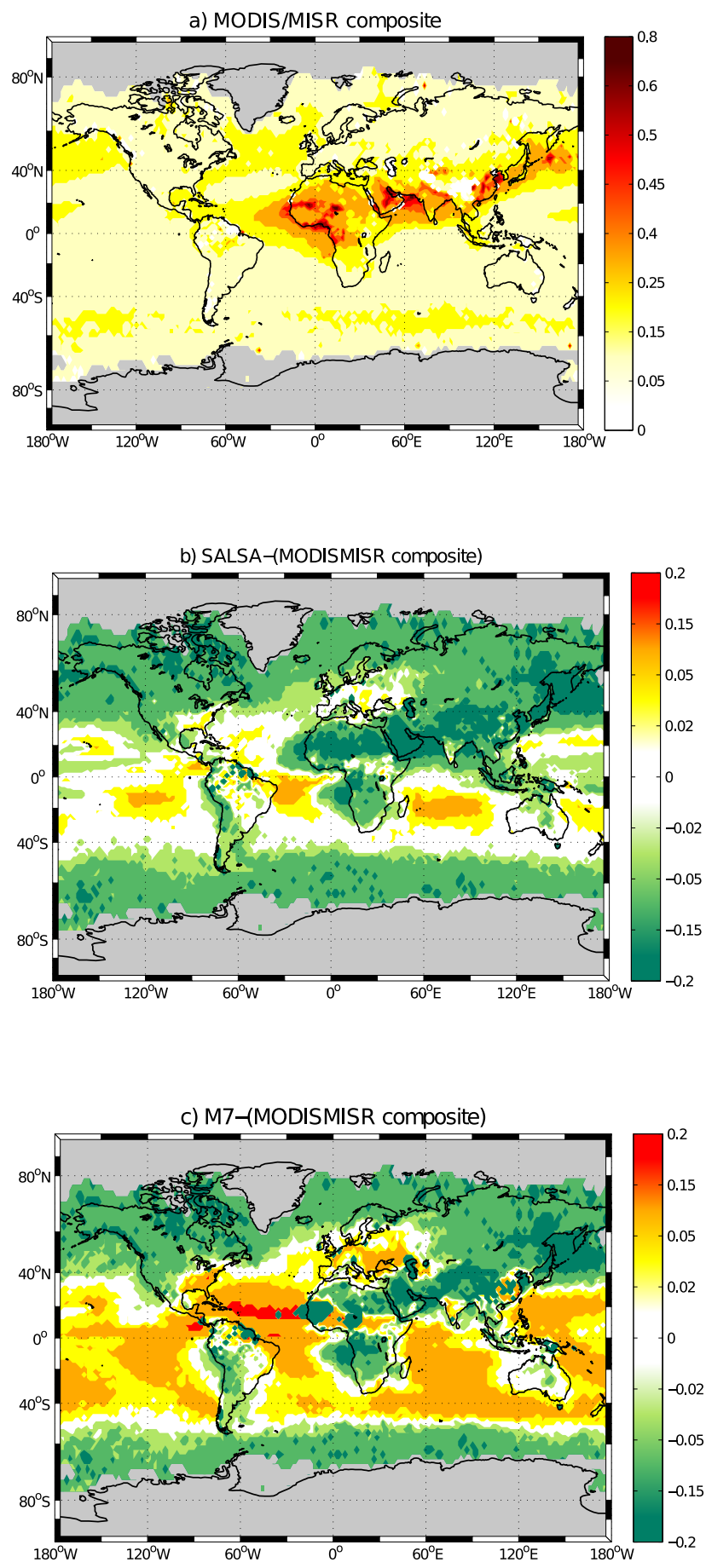

Fig. 9. Composite of retrieved annual mean of aerosol optical depth composite of MODIS and MISR (a). The difference of AODs between MODIS/MISR composite and SALSA (b) and M7 (c). Negative values indicate higher AOD with MODIS/MISR composite. Areas with no data are marked with gray.
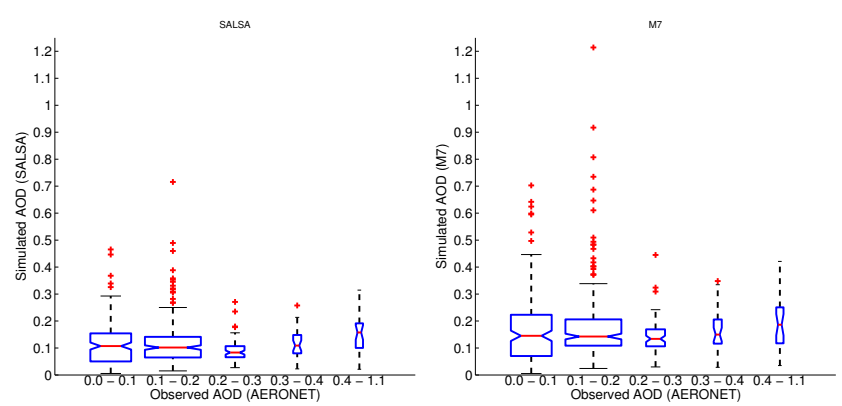

Fig. 10. Box plots of simulated monthly mean AOD at AERONET sites with (a) SALSA and (b) M7. The box plot shows $25 \%$ and $75 \%$ as the box lower and upper boundaries, and the width of the box indicates the relative amount of data. The line in the box shows the median, and the whiskers show the $95 \%$ and $5 \%$ percentiles. The red + signs show the simulated values outside the accepted range (1.5 times the interquantile range). The simulated AODs are grouped to five classes according to observed AOD.

The Ångström exponent

$\mathrm{ANG}=\frac{\ln \mathrm{AOD}_{1}-\ln \mathrm{AOD}_{2}}{\ln \lambda_{2}-\ln \lambda_{1}}$

provides information on the absorption and scattering of radiation, depending on the aerosol size within the air column. Smaller numbers indicate higher optical importance of coarse particles, while larger Ångström exponent indicates stronger influence of accumulation size particles on the radiative transfer. Mean for MODIS over oceans is 0.74 , while the models show much higher Ångström exponent, with 1.39 and 1.13 for M7 and SALSA, respectively. As the Ångström exponent is a qualitative parameter, the overall distribution of the parameter is more important than its exact values. SALSA has a similar spatial distribution compared to the satellite retrieval over oceans, as the smallest Angström exponent values are found over the Southern Ocean and west of Sahara. However, the magnitude is clearly too low, indicating that over oceans there should be fewer large particles than either of the models predict.

\section{Conclusions}

In this study, we have implemented and evaluated the Sectional Aerosol module for Large Scale Applications (SALSA) within aerosol-climate model ECHAM5-HAM. SALSA consists of an optimised sectional structure with 10 size classes having parallel chemical compositions totaling in 20 sections. Simulated constituents include sulphate, organic carbon, black carbon, sea salt and dust. The differences to the HAM default aerosol microphysical model M7 have been descibed in detail. The major difference to M7 (or any modal model) is that SALSA has more flexibility in representation of the size distribution shape, which is a great advantage especially in modelling cloud droplet activation and/or 

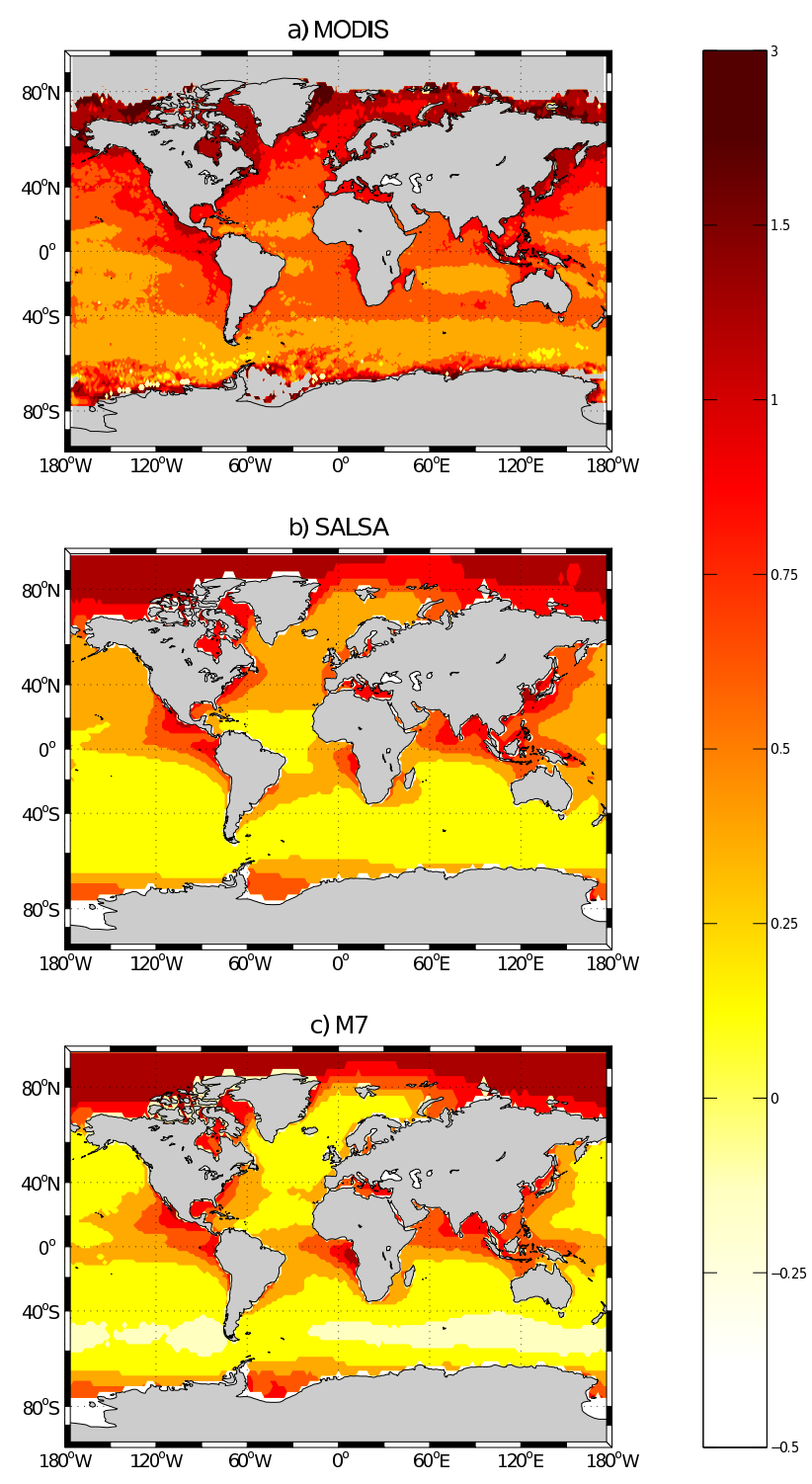

Fig. 11. Simulated and satellite retrieved annual mean Ångström exponent of MODIS $(550 / 865 \mathrm{~nm})$, SALSA $(550 \mathrm{~nm} / 825 \mathrm{~nm})$ and M7 $(550 \mathrm{~nm} / 825 \mathrm{~nm})$ for year 2008 . Gray areas either have no data or have been omitted.

new particle formation. For the evaluation we have simulated the aerosol population for year 2008. The number and mass concentrations are compared with other models and observations.

The global annual mean aerosol column burdens fall mostly within results from other models included in the AeroCom intercomparison (Textor et al., 2006) and Liu et al. (2005b). On average, the surface mass concentrations of organic carbon, black carbon, $\mathrm{SO}_{4}$ and sea salt are close to observed but slightly underestimated. In case of organic carbon, black carbon and $\mathrm{SO}_{4}$ changes of emissions of these compounds between 2000 and 2008 play a clear role. This should be investigated by using emission inventories and observations for the same year including observations from South America, Asia and Africa.

Annual median size distributions when binary nucleation was used show similar number concentrations as M7. However, for both models the number concentrations are almost one order of magnitude lower than observed (Fig. 5). For the simulation run when activation-type boundary layer nucleation was used, the number concentration of particles smaller than $50 \mathrm{~nm}$ in diameter shows better agreement with observations than using binary nucleation. However, the growth of these particles is too low and $50 \mathrm{~nm}$ to $200 \mathrm{~nm}$ diameter particle concentrations are lower than observed. One reason for too limited growth is the lack of organic vapors in this study. The effect of organic vapors on the growth of particles will be studied in the future. The frequencies of particle concentrations of particles between $100 \mathrm{~nm}$ and $500 \mathrm{~nm}$ in diameter (Fig. 6), an important size range for cloud activation, show somewhat infrequent high concentrations with SALSA although compared to M7 the histograms are closer to the observed. Latitudinal annual mean aerosol concentrations over oceans capture the observed size distributions well (Fig. 8). The agreement with observations is especially good for particles $0.1-1.0 \mu \mathrm{m}$ in diameter. Although the concentrations of particles smaller than $50 \mathrm{~nm}$ in diameter are increased using activation-type nucleation, the change in AOD remains negligible, which is supported by the fact that the number concentrations of optically active particles remain very close to those produced by binary nucleation.

The modelled global annual mean AOD with SALSA was found to be lower than the composite of satellite retrievals and lower than AERONET. The most significant contributions to global AOD come from Saharan dust and from polluted areas in India and China. However, the simulated AOD is in good agreement with MODIS-MISR satellite composite over tropical oceans and parts of EU and USA when using SALSA (Fig. 9). Since the high-latitude AOD is underestimated and tropical AOD close to satellite retrievals the global annual mean AOD is underpredicted. Therefore, the aerosol emissions and transport into polar regions need to be studied in the future. Nevertheless, very few number of sections is needed to produce AOD close to observed especially over oceans. This is achieved by carefully selecting correct size class widths, compositions and external mixing in the size distribution.

Modelled Ångström exponent distribution has the lowest values over the Southern Ocean and west of Saharan Desert as also seen in the MODIS retrieval, indicating a significant contribution of sea salt particles over these areas while also Saharan Desert dust affects the Ångström exponent.

Although in many aspects SALSA performs adequately, further improvement is needed: (1) the growth of particles $50-300 \mathrm{~nm}$ in diameter is underestimated and the effect of organic vapors on the growth should be investigated in the near future. (2) The poleward transport of aerosols depends 
largely on their removal by wet deposition. Thus, the calculation of wet deposition should be modified for the sparse sectional structure. (3) The mass of different compounds should be investigated using emissions and observations for the same year and should broaden the observations to include all the continents. In addition, the change of using sectional distribution of emissions instead of M7 modal parameters should be investigated. (4) Recent advances in remote sensing of vertical distribution of aerosols as well as in-situ measurements onboard aircrafts should be used to validate the vertical distribution of aerosols in SALSA.

Acknowledgements. This work was supported by the Academy of Finland (project 119741). S. Romakkaniemi has been supported by the strategic funding of the University of Eastern Finland. We thank Ari Asmi for providing the observational size distribution data for EUCAARI measurement sites and Max Planck Institute for Meteorology for access to ECHAM5-HAM model.

Edited by: O. Boucher

\section{References}

Acker, J. G. and Leptoukh, G.: Online Analysis Enhances Use of NASA Earth Science Data, Eos, Trans. AGU, 88, 14, doi:10.1029/2007EO020003, 2007.

Adams, P. J. and Seinfeld, J. H.: Predicting global aerosol size distributions in general circulation models, J. Geophys. Res., 107, 4370, doi:10.1029/2001JD001010, 2002.

Andreas, E. L.: A New Sea Spray Generation Function for Wind Speeds up to $32 \mathrm{~ms}^{-1}$, J. Phys. Oceanogr., 28, 2175-2184, doi:10.1175/1520-0485(1998)028<2175:ANSSGF>2.0.CO;2, 1998.

Andres, R. J. and Kasgnoc, A. D.: A time-averaged inventory of subaerial volcanic sulfur emissions, J. Geophys. Res., 103, 25251-25261, doi:10.1029/98JD02091, 1998.

Asmi, A., Wiedensohler, A., Laj, P., Fjaeraa, A.-M., Sellegri, K., Birmili, W., Weingartner, E., Baltensperger, U., Zdimal, V., Zikova, N., Putaud, J.-P., Marinoni, A., Tunved, P., Hansson, H.C., Fiebig, M., Kivekäs, N., Lihavainen, H., Asmi, E., Ulevicius, V., Aalto, P. P., Swietlicki, E., Kristensson, A., Mihalopoulos, N., Kalivitis, N., Kalapov, I., Kiss, G., de Leeuw, G., Henzing, B., Harrison, R. M., Beddows, D., O'Dowd, C., Jennings, S. G., Flentje, H., Weinhold, K., Meinhardt, F., Ries, L., and Kulmala, M.: Number size distributions and seasonality of submicron particles in Europe 2008-2009, Atmos. Chem. Phys., 11, 5505-5538, doi:10.5194/acp-11-5505-2011, 2011.

Bauer, S. E., Wright, D. L., Koch, D., Lewis, E. R., McGraw, R., Chang, L.-S., Schwartz, S. E., and Ruedy, R.: MATRIX (Multiconfiguration Aerosol TRacker of mIXing state): an aerosol microphysical module for global atmospheric models, Atmos. Chem. Phys., 8, 6003-6035, doi:10.5194/acp-8-60032008, 2008.

Binkowski, F. S. and Roselle, S. J.: Models-3 Community Multiscale Air Quality (CMAQ) model aerosol component 1. Model description, J. Geophys. Res., 108, 4183, doi:10.1029/2001JD001409, 2003.
Bourgeois, Q. and Bey, I.: Pollution transport efficiency toward the Arctic: Sensitivity to aerosol scavengin and source regions, J. Geophys. Res., 116, D08213, doi:10.1029/2010JD015096, 2011. de Leeuw, G., Andreas, E. L., Anguelova, M. D., Fairall, C. W., Lewis, E., O’Dowd, C., Schulz, M., and Schwartz, S. E.: Production flux of sea spray aerosol, Rev. Geophys., 49, RG2001, doi:10.1029/2010RG000349, 2011.

Dentener, F., Kinne, S., Bond, T., Boucher, O., Cofala, J., Generoso, S., Ginoux, P., Gong, S., Hoelzemann, J. J., Ito, A., Marelli, L., Penner, J. E., Putaud, J.-P., Textor, C., Schulz, M., van der Werf, G. R., and Wilson, J.: Emissions of primary aerosol and precursor gases in the years 2000 and 1750 prescribed data-sets for AeroCom, Atmos. Chem. Phys., 6, 4321-4344, doi:10.5194/acp-64321-2006, 2006.

Downing, H. D. and Williams, D.: Optical-constants of water in infrared, J. Geophys. Res., 80, 1656-1661, 1975.

Engler, C., Rose, D., Wehner, B., Wiedensohler, A., Brüggemann, E., Gnauk, T., Spindler, G., Tuch, T., and Birmili, W.: Size distributions of non-volatile particle residuals $\left(D_{p}<800 \mathrm{~nm}\right)$ at a rural site in Germany and relation to air mass origin, Atmos. Chem. Phys., 7, 5785-5802, doi:10.5194/acp-7-5785-2007, 2007.

Feichter, J., Kjellström, E., Rodhe, H., Dentener, F., Lelieveldi, J., and Roelofs, G.-J.: Simulation of the tropospheric sulfur cycle in a global climate model, Atmos. Environ., 30, 1693-1707, doi:10.1016/1352-2310(95)00394-0, 1996.

Forster, P., Ramaswamy, V., Artaxo, P., Berntsen, T., Betts, R., Fahey, D. W., Haywood, J., Lean, J., Lowe, D. C., Myhre, G., Nganga, J., Prinn, R., Raga, G., Schulz, M., and Van Dorland, R.: Climate Change 2007: The Physical Science Basis. Contribution of Working Group I to the Fourth Assessment Report of the Intergovernmental Panel on Climate Change, chap. Changes in Atmospheric Constituents and in Radiative Forcing, Cambridge University Press, Cambridge, United Kingdom and New York, NY, USA, 2007.

Ganzeveld, L. and Lelieveld, J.: Dry deposition parameterization in a chemistry general circulation model and its influence on the distribution of reactive trace gases, J. Geophys. Res., 100, 20999-21012, doi:10.1029/95JD02266, 1995.

Ganzeveld, L., Lelieveld, J., and Roelofs, G.-J.: A dry deposition parameterization for sulfur oxides in a chemistry and general circulation model, J. Geophys. Res., 103, 5679-5694, 1998.

Ghan, S. J. and Schwartz, S. E.: Aerosol properties and processes. A path from field and laboratory measurements to global climate models, B. Am. Meteorol. Soc., 88, 1059-10832, 2007.

Gilardoni, S., Vignati, E., Marmer, E., Cavalli, F., Belis, C., Gianelle, V., Loureiro, A., and Artaxo, P.: Sources of carbonaceous aerosol in the Amazon basin, Atmos. Chem. Phys., 11, 27472764, doi:10.5194/acp-11-2747-2011, 2011.

Gong, S. L.: A parameterization of sea-salt aerosol source function for sub- and super-micron particles, Global Biogeochem. Cy., 17, 1097, doi:10.1029/2003GB002079, 2003.

Granier, C., Bessagnet, B., Bond, T., D’Angiola, A., van der Gon, H., Frost, G., Heil, A., Kaiser, J., Kinne, S., Klimont, Z., Kloster, S., Lamarque, J.-F., Liousse, C., Masui, T., Meleux, F., Mieville, A., Ohara, T., Raut, J.-C., Riahi, K., Schultz, M., Smith, S., Thompson, A., van Aardenne, J., van der Werf, G., and van Vuuren, D.: Evolution of anthropogenic and biomass burning emissions of air pollutants at global and regional scales during the 1980-2010 period, Climatic Change, 109, 163-190, 
doi:10.1007/s10584-011-0154-1, 2011.

Guelle, W., Schulz, M., Balkanski, Y., and Dentener, F.: Influence of the source formulation on modeling the atmospheric global distribution of sea salt aerosol, J. Geophys. Res., 106, 2750927524, doi:10.1029/2001JD900249, 2001.

Hari, P. and Kulmala, M.: Station for Measuring EcosystemAtmosphere Relations (SMEAR II), Boreal Environ. Res., 10, 315-322, 2005.

Heintzenberg, J., Covert, D. C., and van Dingenen, R.: Size distribution and chemical composition of marine aerosols: a compilation and review, Tellus, 52B, 1104-1122, 2000.

Hess, M., Koepke, P., and Schult, I.: Optical properties of aerosols and clouds: The software package OPAC, B. Am. Meteorol. Soc., 79, 831-844, 1998.

Holben, B., Eck, T. F., Slutsker, I., Tanre, D., Buis, J. P., Setzer, A., Vermote, E., Reagan, J. A., Kaufman, Y. J., Nakajima, T., Lavenu, F., Jankowiak, I., and Smirnov, A.: AERONET-A federated instrument network and data archive for aerosol characterization, Remote Sens. Environ., 66, 1-16, 1998.

Holben, B. N., Tanré, D., Smirnov, A., Eck, T. F., Slutsker, I., Abuhassan, N., Newcomb, W. W., Schafer, J. S., Chatenet, B., Lavenu, F., Kaufman, Y. J., Castle, J. V., Setzer, A., Markham, B., Frouin, D. C. R., Halthore, R., Karneli, A., O’Neill, N. T., Pietras, C., Pinker, R. T., Voss, K., and Zibordi, G.: An emerging ground-based aerosol climatology: Aerosol optical depth from AERONET, J. Geophys. Res., 106, 12067-12098, 2001.

Hoose, C., Lohmann, U., Stier, P., Verheggen, B., and Weingartner, E.: Aerosol processing in mixed-phase clouds in ECHAM5HAM: Model description and comparison to observations, J. Geophys. Res., 113, D07218, doi:10.1029/2007JD009251, 2008.

Horowitz, L. W., Walters, S., Mauzerall, D. L., Emmons, L. K., Rasch, P. J., Granier, C., Tie, X., Lamarque, J.-F., Schulz, M. G., Tyndall, G. S., Orlando, J. J., and Brasseur, G. P.: A global simulation of tropospheric ozone and related tracers: Description and evaluation of MOZART, version 2, J. Geophys. Res., 108, 4784, doi:10.1029/2002JD002853, 2003.

Jacobson, M.: Global direct radiative forcing due to multicomponent anthropogenic and natural aerosols, J. Geophys. Res., 106, 1551-1568, 2001.

Jacobson, M. Z.: Numerical Techniques to Solve Condesational and Dissolutional Growth Equations When Growth is Coupled to Reversible Reactions, Aerosol Sci. Technol., 27, 491-498, 1997a.

Jacobson, M. Z.: Development and application of a new air pollution modeling system II, Aerosol module structure and design, Atmos. Environ., 31, 131-144, doi:10.1016/13522310(96)00202-6, $1997 \mathrm{~b}$.

Jacobson, M. Z.: Analysis of aerosol interactions with numerical techniques for solving coagulation, nucleation, condensation, dissolution and reversible chemistry among multiple size distributions, Aerosol Sci. Technol., 27, 491-498, 2002.

Jacobson, M. Z.: Fundamentals of Atmospheric Modeling, 2nd Edn., Cambridge University Press, New York, 2005.

Jathar, S. H., Farina, S. C., Robinson, A. L., and Adams, P. J.: The influence of semi-volatile and reactive primary emissions on the abundance and properties of global organic aerosol, Atmos. Chem. Phys., 11, 7727-7746, doi:10.5194/acp-11-77272011, 2011.

Jennings, S., O’Dowd, C., O’Connor, T., and McGovern, F.: Physical characteristics of the ambient aerosol at mace head, At- mos. Environ., 25, 557-562, doi:10.1016/0960-1686(91)900529, 1991

Jeuken, A. B. M., Siegmund, P. C., Heijboer, L. C., Feichter, J., and Bengtsson, L.: On the potential of assimilating meteorological analyses in a global climate model for the purpose of model validation, J. Geophys. Res., 101, 16939-16950, 1996.

Jurányi, Z., Gysel, M., Weingartner, E., Bukowiecki, N., Kammermann, L., and Baltensperger, U.: A 17 month climatology of the cloud condensation nuclei number concentration at the high alpine site Jungfraujoch, J. Geophys. Res., 116, D10204, doi:10.1029/2010JD015199, 2011.

Kahn, R., Gaitley, B., Martonchik, J., Diner, D., Crean, K., and Holben, B.: Multiangle Imaging Spectroradiometer (MISR) global aerosol optical depth validation based on 2 years of coincident Aerosol Robotic Network (AERONET) observations, J. Geophys. Res., 110, D10S04, doi:10.1029/2004JD004706, 2005.

Kazil, J., Stier, P., Zhang, K., Quaas, J., Kinne, S., O’Donnell, D., Rast, S., Esch, M., Ferrachat, S., Lohmann, U., and Feichter, J.: Aerosol nucleation and its role for clouds and Earth's radiative forcing in the aerosol-climate model ECHAM5-HAM, Atmos. Chem. Phys., 10, 10733-10752, doi:10.5194/acp-1010733-2010, 2010.

Kerkweg, A., Buchholz, J., Ganzeveld, L., Pozzer, A., Tost, H., and Jöckel, P.: Technical Note: An implementation of the dry removal processes DRY DEPosition and SEDImentation in the Modular Earth Submodel System (MESSy), Atmos. Chem. Phys., 6, 4617-4632, doi:10.5194/acp-6-4617-2006, 2006.

Kerminen, V. and Kulmala, M.: Analytical formulae connecting the "real" and the "apparent" nucleation rate and the nuclei number concentration for atmospheric nucleation events, J. Aerosol Sci., 33, 609-622, 2002.

Kinne, S., Lohmann, U., Feichter, J., Schulz, M., Timmreck, C., Ghan, S., Easter, R., Chin, M., Ginoux, P., Takemura, T., Tegen, I., Koch, D., Herzog, M., Penner, J., Pitari, G., Holben, B., Eck, T., Smirnov, A., Dubovik, O., Slutsker, I., Tanre, D., Torres, O., Mishchenko, M., Geogdzhayev, I., A., C. D., and Kaufman, Y.: Monthly averages of aerosol properties: A global comparison among models, satellite data, and AERONET ground data, J. Geophys. Res., 108, 4634, doi:10.1029/2004JD004999, 2003.

Koch, D., Schulz, M., Kinne, S., McNaughton, C., Spackman, J. R., Balkanski, Y., Bauer, S., Berntsen, T., Bond, T. C., Boucher, O., Chin, M., Clarke, A., De Luca, N., Dentener, F., Diehl, T., Dubovik, O., Easter, R., Fahey, D. W., Feichter, J., Fillmore, D., Freitag, S., Ghan, S., Ginoux, P., Gong, S., Horowitz, L., Iversen, T., Kirkevåg, A., Klimont, Z., Kondo, Y., Krol, M., Liu, X., Miller, R., Montanaro, V., Moteki, N., Myhre, G., Penner, J. E., Perlwitz, J., Pitari, G., Reddy, S., Sahu, L., Sakamoto, H., Schuster, G., Schwarz, J. P., Seland, Ø., Stier, P., Takegawa, N., Takemura, T., Textor, C., van Aardenne, J. A., and Zhao, Y.: Evaluation of black carbon estimations in global aerosol models, Atmos. Chem. Phys., 9, 9001-9026, doi:10.5194/acp-9-9001-2009, 2009.

Koepke, P., Hess, M., Schult, I., and Shettle, E.: Global Aerosol Data Set, Tech. rep., Max-Planck Institute for Meteorology, 1997.

Kokkola, H., Korhonen, H., Lehtinen, K. E. J., Makkonen, R., Asmi, A., Järvenoja, S., Anttila, T., Partanen, A.-I., Kulmala, M., Järvinen, H., Laaksonen, A., and Kerminen, V.-M.: SALSA - a Sectional Aerosol module for Large Scale Applications, At- 
mos. Chem. Phys., 8, 2469-2483, doi:10.5194/acp-8-2469-2008, 2008.

Korhonen, H., Carslaw, K. S., Spracklen, D. V., Ridley, D. A., and Ström, J.: A global model study of processes controlling aerosol size distributions in the Arctic spring and summer, J. Geophys. Res., 113, D08211, doi:10.1029/2007JD009114, 2008.

Kulmala, M., Lehtinen, K. E. J., and Laaksonen, A.: Cluster activation theory as an explanation of the linear dependence between formation rate of $3 \mathrm{~nm}$ particles and sulphuric acid concentration, Atmos. Chem. Phys., 6, 787-793, doi:10.5194/acp-6-787-2006, 2006.

Kulmala, M., Asmi, A., Lappalainen, H. K., Carslaw, K. S., Pöschl, U., Baltensperger, U., Hov, Ø., Brenquier, J.-L., Pandis, S. N., Facchini, M. C., Hansson, H.-C., Wiedensohler, A., and O'Dowd, C. D.: Introduction: European Integrated Project on Aerosol Cloud Climate and Air Quality interactions (EUCAARI) - integrating aerosol research from nano to global scales, Atmos. Chem. Phys., 9, 2825-2841, doi:10.5194/acp-9-2825-2009, 2009.

Kulmala, M., Asmi, A., Lappalainen, H. K., Baltensperger, U., Brenguier, J.-L., Facchini, M. C., Hansson, H.-C., Hov, Ø., O’Dowd, C. D., Pöschl, U., Wiedensohler, A., Boers, R., Boucher, O., de Leeuw, G., Denier van der Gon, H. A. C., Feichter, J., Krejci, R., Laj, P., Lihavainen, H., Lohmann, U., McFiggans, G., Mentel, T., Pilinis, C., Riipinen, I., Schulz, M., Stohl, A., Swietlicki, E., Vignati, E., Alves, C., Amann, M., Ammann, M., Arabas, S., Artaxo, P., Baars, H., Beddows, D. C. S., Bergström, R., Beukes, J. P., Bilde, M., Burkhart, J. F., Canonaco, F., Clegg, S. L., Coe, H., Crumeyrolle, S., D’Anna, B., Decesari, S., Gilardoni, S., Fischer, M., Fjaeraa, A. M., Fountoukis, C., George, C., Gomes, L., Halloran, P., Hamburger, T., Harrison, R. M., Herrmann, H., Hoffmann, T., Hoose, C., Hu, M., Hyvärinen, A., Hõrrak, U., Iinuma, Y., Iversen, T., Josipovic, M., Kanakidou, M., Kiendler-Scharr, A., Kirkevåg, A., Kiss, G., Klimont, Z., Kolmonen, P., Komppula, M., Kristjánsson, J.-E., Laakso, L., Laaksonen, A., Labonnote, L., Lanz, V. A., Lehtinen, K. E. J., Rizzo, L. V., Makkonen, R., Manninen, H. E., McMeeking, G., Merikanto, J., Minikin, A., Mirme, S., Morgan, W. T., Nemitz, E., O’Donnell, D., Panwar, T. S., Pawlowska, H., Petzold, A., Pienaar, J. J., Pio, C., Plass-Duelmer, C., Prévôt, A. S. H., Pryor, S., Reddington, C. L., Roberts, G., Rosenfeld, D., Schwarz, J., Seland, Ø., Sellegri, K., Shen, X. J., Shiraiwa, M., Siebert, H., Sierau, B., Simpson, D., Sun, J. Y., Topping, D., Tunved, P., Vaattovaara, P., Vakkari, V., Veefkind, J. P., Visschedijk, A., Vuollekoski, H., Vuolo, R., Wehner, B., Wildt, J., Woodward, S., Worsnop, D. R., van Zadelhoff, G.-J., Zardini, A. A., Zhang, K., van Zyl, P. G., Kerminen, V.-M., S Carslaw, K., and Pandis, S. N.: General overview: European Integrated project on Aerosol Cloud Climate and Air Quality interactions (EUCAARI) - integrating aerosol research from nano to global scales, Atmos. Chem. Phys., 11, 13061-13143, doi:10.5194/acp11-13061-2011, 2011.

Lehtinen, K., Rannik, U., Petäjä, T., Kulmala, M., and Hari, P.: Nucleation rate and vapor concentration estimations using a leastsquares aerosol dynamics method, J. Geophys. Res. Atmos., 109, D21209, doi:10.1029/2004JD004893, 2004.

Lesins, G., Chylek, P., and Lohmann, U.: A study of internal and external mixing scenarios and its effect on aerosol optical properties and direct radiative forcing, J. Geophys. Res., 107, 4094,
doi:10.1029/2001JD000973, 2002.

Levy, R. C., Remer, L. A., Kleidman, R. G., Mattoo, S., Ichoku, C., Kahn, R., and Eck, T. F.: Global evaluation of the Collection 5 MODIS dark-target aerosol products over land, Atmos. Chem. Phys., 10, 10399-10420, doi:10.5194/acp-10-10399-2010, 2010.

Liao, H., Zhang, Y., Chen, W.-T., Raes, F., and Seinfeld, J. H.: Effect of chemistry-aerosol-climate coupling on predictions of future climate and future levels of tropospheric ozone and aerosols, J. Geophys. Res., 114, D10306, doi:10.1029/2008JD010984, 2009.

Lihavainen, H., Kerminen, V.-M., Komppula, M., Hyvärinen, A.-P., Laakia, J., Saarikoski, S., Makkonen, U., Kivekäs, N., Hillamo, R., Kulmala, M., and Viisanen, Y.: Measurements of the relation between aerosol properties and microphysics and chemistry of low level liquid water clouds in Northern Finland, Atmos. Chem. Phys., 8, 6925-6938, doi:10.5194/acp-8-6925-2008, 2008.

Lin, S.-J. and Rood, R. B.: Multidimensional Flux-Form Semi-Lagrangian Transport Schemes, MWR, 124, 2046-2070, doi:10.1175/15200493(1996)124253C2046:MFFSLT253E2.0.CO;2, 1996.

Liu, H. Q., Pinker, R. T., and Holben, B. N.: A global view of aerosols from merged transport models, satellite, and ground observations, J. Geophys. Res., 110, D10S15, doi:10.1029/2004JD004695, 2005a.

Liu, X., Penner, J. E., and Herzog, M.: Global modeling of aerosol dynamics: Model description, evaluation, and interactions between sulfate and nonsulfate aerosols, J. Geophys. Res., 110, D18206, doi:10.0129/2004JD005674, 2005b.

Lohmann, U., Stier, P., Hoose, C., Ferrachat, S., Kloster, S., Roeckner, E., and Zhang, J.: Cloud microphysics and aerosol indirect effects in the global climate model ECHAM5-HAM, Atmos. Chem. Phys., 7, 3425-3446, doi:10.5194/acp-7-3425-2007, 2007.

Mann, G. W., Carslaw, K. S., Spracklen, D. V., Ridley, D. A., Manktelow, P. T., Chipperfield, M. P., Pickering, S. J., and Johnson, C. E.: Description and evaluation of GLOMAP-mode: a modal global aerosol microphysics model for the UKCA composition-climate model, Geosci. Model Dev., 3, 519-551, doi:10.5194/gmd-3-519-2010, 2010.

Martonchik, J., Diner, D. J., Kahn, R., Ackerman, T. P., Verstraete, M. M.and Pinty, B., and Gordon, H. R.: Techniques for the retrieval of aerosol properties over land and ocean using multiangle imaging, IEEE Trans. Geosci. Remote Sens., 36, 1212 1227, 1998.

Mayol-Bracero, O. L., Guyon, P., Graham, B., Roberts, G., Andreae, M. O., Decesari, S., Facchini, M. C., Fuzzi, S., and Artaxo, P.: Water-soluble organic compounds in biomass burning aerosols over Amazonia 2. Apportionment of the chemical composition and importance of the polyacidic fraction, J. Geophys. Res., 107, 8091, doi:10.1029/2001JD000522, 2002.

Mielonen, T., Levy, R. C., Aaltonen, V., Komppula, M., de Leeuw, G., Huttunen, J., Lihavainen, H., Kolmonen, P., Lehtinen, K. E. J., and Arola, A.: Evaluating the assumptions of surface reflectance and aerosol type selection within the MODIS aerosol retrieval over land: the problem of dust type selection, Atmos. Meas. Tech., 4, 201-214, doi:10.5194/amt-4-201-2011, 2011.

Monahan, E. C., Spiel, D. E., and Davidson, K. L.: A model of marine aerosol generation via whitecaps and wave disruption, in: Oceanic Whitecaps and Their Role in Air-Sea Exchange, edited by: Monahan, E. and Mac Niocaill, G., D. Reidel, Norwell, Mas- 
sachusetts, 167-174, 1986.

Myhre, G.: Consistency Between Satellite-Derived and Modeled Estimates of the Direct Aerosol Effect, Science, 325, 187-190, doi:10.1126/science.1174461, 2009.

Nightingale, P. D., Malin, G., Law, C. S., Watson, A. J., Liss, P. S., Liddicoat, M. I., Boutin, J., and Upstill-Goddard, R. C.: In situ evaluation of air-sea gas exchange parameterizations using novel conservative and volatile tracers, Global Biogeochem. Cy., 14, 373-387, doi:10.1029/1999GB900091, 2000.

O'Donnell, D., Tsigaridis, K., and Feichter, J.: Estimating the direct and indirect effects of secondary organic aerosols using ECHAM5-HAM, Atmos. Chem. Phys., 11, 8635-8659, doi:10.5194/acp-11-8635-2011, 2011.

Partanen, A.-I., Kokkola, H., Romakkaniemi, S., Kerminen, V.-M., Lehtinen, K., Bergman, T., Arola, A., and Korhonen, H.: Direct and indirect effects of sea spray geoengineering and the role of injected particle size, J. Geophys. Res., 117, D02203, doi:10.1029/2011JD016428, 2012.

Pham, M., Mueller, J. F., Brasseur, G., Granier, C., and Megie, C.: A three-dimensional study of the tropospheric sulfate cycle, J. Geophys. Res., 100, 26061-26092, doi:10.1029/95JD02095, 1995.

Pinty, B., Taberner, M., Haemmerle, V. R., Paradise, S. R., Vermote, E., Verstraete, M. M., Gobron, N., and Widlowski, J.-L.: GlobalScale Comparison of MISR and MODIS Land Surface Albedos, J. Climate, 24, 732-749, doi:10.1175/2010JCLI3709.1, 2010.

Pringle, K. J., Tost, H., Message, S., Steil, B., Giannadaki, D., Nenes, A., Fountoukis, C., Stier, P., Vignati, E., and Lelieveld, J.: Description and evaluation of GMXe: a new aerosol submodel for global simulations (v1), Geosci. Model Dev., 3, 391-412, doi:10.5194/gmd-3-391-2010, 2010.

Quaas, J., Ming, Y., Menon, S., Takemura, T., Wang, M., Penner, J. E., Gettelman, A., Lohmann, U., Bellouin, N., Boucher, O., Sayer, A. M., Thomas, G. E., McComiskey, A., Feingold, G., Hoose, C., Kristjánsson, J. E., Liu, X., Balkanski, Y., Donner, L. J., Ginoux, P. A., Stier, P., Grandey, B., Feichter, J., Sednev, I., Bauer, S. E., Koch, D., Grainger, R. G., Kirkevåg, A., Iversen, T., Seland, Ø., Easter, R., Ghan, S. J., Rasch, P. J., Morrison, H., Lamarque, J.-F., Iacono, M. J., Kinne, S., and Schulz, M.: Aerosol indirect effects - general circulation model intercomparison and evaluation with satellite data, Atmos. Chem. Phys., 9, 8697-8717, doi:10.5194/acp-9-8697-2009, 2009.

Reddy, M. S., Boucher, O., Bellouin, N., Schulz, M., Balkanski, Y., Dufresne, J.-L., and Pham, M.: Estimates of global multicomponent aerosol optical depth and direct radiative perturbation in the Laboratoire de Météorologie Dynamique general circulation model, J. Geophys. Res., 110, D10S16, doi:10.1029/2004JD004757, 2005.

Remer, L. A., Kaufman, Y. J., Tanré, D., Mattoo, S., Chu, D. A., Martins, J. V., Li, R. R., Ichoku, C., Levy, R. C., Kleidman, R. G., Eck, T. F., Vermote, E., and Holben, B. N.: The MODIS Aerosol Algorithm, Products, and Validation, J. Atmos. Sci., 62, 947-973, doi:10.1175/JAS3385.1, 2005.

Riipinen, I., Sihto, S.-L., Kulmala, M., Arnold, F., Dal Maso, M., Birmili, W., Saarnio, K., Teinilä, K., Kerminen, V.-M., Laaksonen, A., and Lehtinen, K. E. J.: Connections between atmospheric sulphuric acid and new particle formation during QUEST III-IV campaigns in Heidelberg and Hyytiälä, Atmos. Chem. Phys., 7, 1899-1914, doi:10.5194/acp-7-1899-2007, 2007.
Riipinen, I., Pierce, J. R., Yli-Juuti, T., Nieminen, T., Häkkinen, S., Ehn, M., Junninen, H., Lehtipalo, K., Petäjä, T., Slowik, J., Chang, R., Shantz, N. C., Abbatt, J., Leaitch, W. R., Kerminen, V.-M., Worsnop, D. R., Pandis, S. N., Donahue, N. M., and Kulmala, M.: Organic condensation: a vital link connecting aerosol formation to cloud condensation nuclei $(\mathrm{CCN})$ concentrations, Atmos. Chem. Phys., 11, 3865-3878, doi:10.5194/acp-11-38652011, 2011.

Roeckner, E., Bäuml, R., Bonaventura, L., Brokopf, R., Esch, M., Giorgetta, M., Hagemann, S., Kirchner, I., Kornblueh, L., Manzini, E., Rhodin, A., Schlese, U., Schulzweida, U., and Tompkins, A.: The atmospheric general circulation model ECHAM5, Part I: Model description, Tech. rep., Max-Planck Institute for Meteorology, Hamburg, Germany, 2003.

Roeckner, E., Brokopf, R., Esch, M., Giorgetta, M., Hagemann, S., Kornblueh, L., Manzini, E., Schlese, U., and Schulzweida, U.: The atmospheric general circulation model ECHAM5, Part II: Sensitivity of simulated climate to horizontal and vertical resolution, Tech. rep., Max-Planck Institute for Meteorology, Hamburg, Germany, 2004.

Sartelet, K. N., Hayami, H., Albriet, B., and Sportisse, B.: Development and Preliminary Validation of a Modal Aerosol Model for Tropospheric Chemistry: MAM, Aerosol Science and Technology, 40, 118-127, doi:10.1080/02786820500485948, http: //www.tandfonline.com/doi/abs/10.1080/02786820500485948, 2006.

Schwartz, S. E., Charlson, R. J., Kahn, R. A., Ogren, J. A., and Rodhe, H.: Why Hasn't Earth Warmed as Much as Expected?, Journal of Climate, 23, 2453-2464, doi:10.1175/2009JCLI3461.1, 2010.

Seinfeld, J. and Pandis, S.: Atmospheric chemistry and physics: From air pollution to climate change, 2 nd edn., Wiley Interscience, 2006.

Sesartic, A., Lohmann, U., and Storelvmo, T.: Bacteria in the ECHAM5-HAM global climate model, Atmospheric Chemistry and Physics Discussions, 11, 1457-1488, doi:10.5194/acpd-111457-2011, 2011

Shettle, E. P. and Fenn, R.: Models of the aerosols of the lower atmosphere and the effects of humidity variations on their optical properties, Tech. rep., Air Force Geoph. Lab., Massachusetts, 1979.

Shi, Y., Zhang, J., Reid, J. S., Holben, B., Hyer, E. J., and Curtis, C.: An analysis of the collection 5 MODIS over-ocean aerosol optical depth product for its implication in aerosol assimilation, Atmos. Chem. Phys., 11, 557-565, doi:10.5194/acp-11-557-2011, 2011.

Shindell, D. T., Chin, M., Dentener, F., Doherty, R. M., Faluvegi, G., Fiore, A. M., Hess, P., Koch, D. M., MacKenzie, I. A., Sanderson, M. G., Schultz, M. G., Schulz, M., Stevenson, D. S., Teich, H., Textor, C., Wild, O., Bergmann, D. J., Bey, I., Bian, H., Cuvelier, C., Duncan, B. N., Folberth, G., Horowitz, L. W., Jonson, J., Kaminski, J. W., Marmer, E., Park, R., Pringle, K. J., Schroeder, S., Szopa, S., Takemura, T., Zeng, G., Keating, T. J., and Zuber, A.: A multi-model assessment of pollution transport to the Arctic, Atmos. Chem. Phys., 8, 5353-5372, doi:10.5194/acp-85353-2008, 2008

Sihto, S.-L., Kulmala, M., Kerminen, V.-M., Dal Maso, M., Petäjä, T., Riipinen, I., Korhonen, H., Arnold, F., Janson, R., Boy, M. Laaksonen, A., and Lehtinen, K. E. J.: Atmospheric sulphuric 
acid and aerosol formation: implications from atmospheric measurements for nucleation and early growth mechanisms, Atmos. Chem. Phys., 6, 4079-4091, doi:10.5194/acp-6-4079-2006, 2006.

Sihto, S.-L., Mikkilä, J., Vanhanen, J., Ehn, M., Liao, L., Lehtipalo, K., Aalto, P. P., Duplissy, J., Petäjä, T., Kerminen, V.-M., Boy, M., and Kulmala, M.: Seasonal variation of CCN concentrations and aerosol activation properties in boreal forest, Atmos. Chem. Phys., 11, 13269-13285, doi:10.5194/acp-11-13269-2011, 2011.

Spracklen, D. V., Pringle, K. J., Carslaw, K. S., Chipperfield, M. P., and Mann, G. W.: A global off-line model of sizeresolved aerosol microphysics: I. Model development and prediction of aerosol properties, Atmos. Chem. Phys., 5, 22272252, doi:10.5194/acp-5-2227-2005, 2005.

Spracklen, D. V., Carslaw, K. S., Merikanto, J., Mann, G. W., Reddington, C. L., Pickering, S., Ogren, J. A., Andrews, E., Baltensperger, U., Weingartner, E., Boy, M., Kulmala, M., Laakso, L., Lihavainen, H., Kivekäs, N., Komppula, M., Mihalopoulos, N., Kouvarakis, G., Jennings, S. G., O’Dowd, C., Birmili, W., Wiedensohler, A., Weller, R., Gras, J., Laj, P., Sellegri, K., Bonn, B., Krejci, R., Laaksonen, A., Hamed, A., Minikin, A., Harrison, R. M., Talbot, R., and Sun, J.: Explaining global surface aerosol number concentrations in terms of primary emissions and particle formation, Atmos. Chem. Phys., 10, 4775-4793, doi:10.5194/acp-10-4775-2010, 2010.

Stier, P., Feichter, J., Kinne, S., Kloster, S., Vignati, E., Wilson, J., Ganzeveld, L., Tegen, I., Werner, M., Balkanski, Y., Schulz, M., Boucher, O., Minikin, A., and Petzold, A.: The aerosol-climate model ECHAM5-HAM, Atmos. Chem. Phys., 5, 1125-1156, doi:10.5194/acp-5-1125-2005, 2005.

Stokes, R. and Robinson, R. A.: Interactions in aqueous nonelectrolytes solutions, I, Solute-solvent equilibria, J. Phys. Chem., 70, 2126-2131, 1966.doi:10.1021/j100879a010

Tegen, I., Harrison, S. P., Kohfeld, K., Prentice, I. C., and Coe, M., and Heimann, M.: Impact of vegetation and preferential source areas on global dust aerosol: Results from a model study, J. Geophys. Res., 107, 4576, doi:10.1029/2001JD000963, 2002.

Textor, C., Schulz, M., Guibert, S., Kinne, S., Balkanski, Y., Bauer, S., Berntsen, T., Berglen, T., Boucher, O., Chin, M., Dentener, F., Diehl, T., Easter, R., Feichter, H., Fillmore, D., Ghan, S., Ginoux, P., Gong, S., Grini, A., Hendricks, J., Horowitz, L., Huang, P., Isaksen, I., Iversen, I., Kloster, S., Koch, D., Kirkevåg, A., Kristjansson, J. E., Krol, M., Lauer, A., Lamarque, J. F., Liu, X., Montanaro, V., Myhre, G., Penner, J., Pitari, G., Reddy, S., Seland, $\varnothing$., Stier, P., Takemura, T., and Tie, X.: Analysis and quantification of the diversities of aerosol life cycles within AeroCom, Atmos. Chem. Phys., 6, 1777-1813, doi:10.5194/acp-6-1777-2006, 2006.
Toon, O. B. and Ackerman, T. P.: Algorithms for the calculation of scattering by stratified spheres, Appl. Optics, 20, 3657-3660, 1981.

Tunved, P., Ström, J., and Hansson, H.-C.: An investigation of processes controlling the evolution of the boundary layer aerosol size distribution properties at the Swedish background station Aspvreten, Atmos. Chem. Phys., 4, 2581-2592, doi:10.5194/acp-4-2581-2004, 2004.

Uppala, S. M., Kållberg, P. W., Simmons, A. J., Andrae, U., Bechtold, V. D. C., Fiorino, M., Gibson, J. K., Haseler, J., Hernandez, A., Kelly, G. A., Li, X., Onogi, K., Saarinen, S., Sokka, N., Allan, R. P., Andersson, E., Arpe, K., Balmaseda, M. A., Beljaars, A. C. M., Berg, L. V. D., Bidlot, J., Bormann, N., Caires, S., Chevallier, F., Dethof, A., Dragosavac, M., Fisher, M., Fuentes, M., Hagemann, S., Hólm, E., Hoskins, B. J., Isaksen, L., Janssen, P. A. E. M., Jenne, R., Mcnally, A. P., Mahfouf, J.-F., Morcrette, J.-J., Rayner, N. A., Saunders, R. W., Simon, P., Sterl, A., Trenberth, K. E., Untch, A., Vasiljevic, D., Viterbo, P., and Woollen, J.: The ERA-40 re-analysis, Q. J. Roy. Meteorol. Soc., 131, 2961-3012, doi:10.1256/qj.04.176, 2005.

Vehkamäki, H., Kulmala, M., Napari, I., Lehtinen, K. E. J., Timmreck, C., Noppel, M., and Laaksonen, A.: An improved parameterization for sulfuric acid/water nucleation rates for tropospheric and stratospheric conditions, J. Geophys. Res., 107, 4622-4631, 2002.

Vignati, E., Wilson, J., and Stier, P.: M7: An efficient size-resolved aerosol microphysics module for large-scale aerosol transport models, J. Geophys. Res., 109, D22202, doi:10.1029/2003JD004485, 2004.

Yuan, X.: High-wind-speed evaluation in the Southern Ocean, J. Geophys. Res., 109, D13101, doi:10.1029/2003JD004179, 2004.

Zhang, K., Wan, H., Wang, B., Zhang, M., Feichter, J., and Liu, X.: Tropospheric aerosol size distributions simulated by three online global aerosol models using the M7 microphysics module, Atmos. Chem. Phys., 10, 6409-6434, doi:10.5194/acp-10-64092010, 2010.

Zhang, Y., Seigneur, C., Seinfeld, J. H., Jacobson, M. Z., and Binkowski, F. S.: Simulation of Aerosol Dynamics: A Comparative Review of Algorithms Used in Air Quality Models, Aerosol Sci. Technol., 31, 487-514, doi:10.1080/027868299304039, 1999. 